\title{
Female Rank-and-File Accounting Employees and Internal Control Quality*
}

\author{
Chuchu Liang \\ The Paul Merage School of Business \\ University of California, Irvine \\ chuchu.liang@uci.edu \\ Ben Lourie \\ The Paul Merage School of Business \\ University of California, Irvine \\ blourie@uci.edu \\ P. Eric Yeung \\ Johnson Graduate School of Management \\ SC Johnson College of Business \\ Cornell University \\ eric.yeung@cornell.edu
}

\begin{abstract}
We use proprietary data on rank-and-file employees from a large sample to document a negative relation between the percentage of female rank-and-file accounting employees and firms' propensity for internal control weaknesses. This relation is curvilinear. The effect is strong when female accountants are underrepresented, while the effect attenuates when gender diversity exceeds parity. We also find that a firm's ineffective internal control predicts the future turnover of male rank-and-file accountants. Our study is the first to provide evidence that gender plays an important role at the level of rank-and-file employees in determining internal control quality.
\end{abstract}

\section{Keywords}

Internal accountants; Rank-and-file employees; Internal control quality; Gender; Female effects

*We appreciate helpful comments from Liz Chuk, Joanna Ho, Radhika Lunawat, Alex Nekrasov, Mort Pincus, Devin Shanthikumar, Terry Shevlin, Siew Hong Teoh, Chenqi Zhu, workshop participants at University of California-Irvine, and the participants at the 2019 Academic Conference of the Auditing Committee of the Chinese Accounting Society. 


\section{Female Rank-and-File Accounting Employees and Internal Control Quality}

\section{Introduction}

A firm's internal accounting department offers risk management and evaluates the effectiveness of a company's internal controls, corporate governance, and accounting processes. These departments provide management and the board of directors with a value-added service in which the flaws in a process can be discovered and corrected before external audits. Due to data limitations, there is scant research on internal rank-and-file accounting employees and whether the characteristics of these employees affect accounting outcomes. In this paper, we examine the effects of female rank-and-file accounting employees on firms' accounting processes, with an emphasis on internal control quality.

Gender is a salient characteristic that has been shown to affect firm outcomes at the level of top executives and directors. For example, prior research shows that female top executives and directors are associated with higher earnings quality, higher accounting conservatism, higher audit quality, less security fraud, fewer lawsuits, and higher stock price informativeness. ${ }^{1}$ In contrast with women's underrepresentation at the top, ${ }^{2}$ women are at parity among accounting-related jobs in the U.S. (Bureau of Labor Statistics 2019, Table 11). It is thus unclear whether gender has any effect at the rank-and-file employee level. In this study, we provide large-sample evidence on gender's role at the employee level regarding the quality of accounting practices.

The literature suggests that distinct female effects may arise through three mechanisms: ethicality, risk aversion, and diversity. The gender socialization theory suggests that men are

\footnotetext{
${ }^{1}$ See Gul et al. (2011), Srinidhi et al. (2011), Cumming et al. (2015), Francis et al. (2015), Lai et al. (2017), and Adhikari et al. (2019).

${ }^{2}$ For instance, women hold only $6 \%$ of U.S. top executive positions (Matsa and Miller 2011).
} 
guided by agentic goals (i.e., focusing more on the pursuit of personal achievement) while women are guided by communal goals (i.e., placing more emphasis on the development of interpersonal relationships, see, e.g., Carlson 1972). As such, women are more likely to react ethically when faced with dilemmas (e.g., Mason and Mudrack 1996). Consequently, women may be more trustworthy and more compliant with rules and regulations (e.g., Ruegger and King 1992; Barnett et al. 1994; Bernardi and Arnold 1997; Ibrahim 2009). For example, female managers exhibit more positive attitudes toward codes of ethics and show a higher level of moral development (e.g., Bernardi and Arnold 1997; Ibrahim et al. 2009).

Women also tend to be more risk averse, less overconfident, and more likely to focus on strategies that avoid the worst outcomes and maintain their security (e.g., Powell and Ansic 1997; Sunden and Surette 1998; Byrnes et al. 1999; Agnew et al. 2003; Agnew et al. 2008). A risk-averse individual is typically less willing to commit fraud or intentional violations of internal procedures for fear of being caught. The finance literature suggests that overconfident investors tend to hold riskier portfolios (e.g., Odean 1998), and men tend to invest in riskier portfolios than women (e.g., Jianakoplos and Bernasek 1998; Barber and Odean 2001; Olsen and Cox 2001).

Finally, if we assume that males dominate the workforce, more female employees means more gender diversity. ${ }^{3}$ The literature argues that gender diversity in a team may facilitate more effective monitoring because the members of diverse teams complement each other in terms of expertise, experience, interests, and perspectives (e.g., Erhardt et al. 2003; Campbell et al. 2008; Adams and

\footnotetext{
${ }^{3}$ The concern about gender diversity may be less severe at the rank-and-file employee level. In particular, since female rank-and-file accounting employees already make up about $50 \%$ of all accountants, we may not observe any significant benefits of gender diversity. For instance, Frink et al. (2003) find an inverted U-shaped relation between gender composition and organization performance using survey data. Ali et al. (2011) also find a curvilinear relation using Australian data.
} 
Ferreira 2009; Hoever et al. 2012). Thus, we expect that these three distinct mechanisms (i.e., ethicality, risk aversion, and diversity) will lead to better accounting practices.

However, there are several important reasons to expect that a higher proportion of female rankand-file accountants does not have any significant impact on firm-level accounting practices. First, upper echelon theory suggests that individuals at the top level of the corporate hierarchy set the tone for the organization. This is consistent with prior research that focuses on how top executives and directors individually affect corporate decisions (e.g., Hambrick and Mason 1984). It is unclear, therefore, whether female rank-and-file accounting employees matter after controlling for the effects of female employees at the top levels of an organization.

Second, prior studies largely focus on female effects in female-underrepresented populations (e.g., top executives and directors), which can only observe a severely bounded distribution of female proportion (e.g., from zero to 20-percent). The documented female effects in prior literature might arise because only those females with superior abilities can reach the femaleunderrepresented positions due to labor market frictions. In contrast, women already make up about half of all accounting employees, and we can observe a full distribution of female employees (from zero to 100-percent). Thus, findings from prior studies may not be generalizable to the population of internal accountants. It is therefore an open question whether gender at rank-and-file accounting employee level plays a role. ${ }^{4}$

Third, female accountants are paid less, on average. For instance, the Bureau of Labor Statistics (2019, Table 39) shows that the weekly median compensation of female accountants and female auditors is about $20 \%$ lower than that of men in the same field ( $\$ 1,108$ versus $\$ 1,404)$. Given this

\footnotetext{
${ }^{4}$ For instance, it is unclear whether the effect of an increase in the proportion of females from $25 \%$ to $50 \%$ is similar to the effect of an increase from $50 \%$ to $75 \%$. Since female accounting employees are already at parity with male employees, we may not observe any effects, on average.
} 
gender pay disparity, it is unclear whether a higher proportion of lower-paid female accountants generates greater accounting benefits relative to their higher-paid male counterparts.

We focus on the quality of internal control procedures because rank-and-file employees are more likely to affect these practices rather than high-level accounting estimates (e.g., goodwill impairments). ${ }^{5}$ The Securities and Exchange Commission views internal control as "a process that involves human diligence and compliance and is subject to lapses in judgment and breakdowns resulting from human failures" (SEC 2007). Using descriptions of material weaknesses provided by firms' SEC filings, prior studies suggest that a lack of qualified accounting staff is a common cause for ineffective internal controls (Ge and McVay 2005; Doyle et al. 2007). Consistent with this view, about half of internal control weaknesses in our sample are due to employees' competency or ethical/compliance issues as classified by Audit Analytics. This underscores the notion that employee errors are a potentially important contributor to internal control ineffectiveness.

We obtain proprietary rank-and-file employee information from a third-party company that continuously tracks a large number of publicly available online employee profiles. Our final sample has 23,542 firm-year observations, which covers 3,246 U.S. public firms for the period 2007-2017. Using this sample, we find negative associations between the likelihood of (one-yearahead) internal control weaknesses and the percentage of female employees in the accounting department, after controlling for (a) the gender of the CEO or CFO, (b) the percentage of female directors, and (c) the percentage of female rank-and-file non-accounting employees, in addition to other determinants of internal control quality documented in prior studies.

\footnotetext{
${ }^{5}$ Internal control over financial reporting is defined as "a process... to provide reasonable assurance regarding the reliability of financial reporting" (PCAOB, 2004) which aims to prevent or detect errors or fraud that could result in inaccurate financial statements.
} 
Importantly, the negative relation between the percentage of female accounting employees and the likelihood of internal control weaknesses is nonlinear. This relation is strong when female accountants are underrepresented, and it plateaus when gender diversity exceeds parity. This is consistent with a curvilinear relation (e.g., Frink et al. 2003; Ali et al. 2011). The percentage of female accountants is also negatively associated with employee-specific internal control weaknesses (i.e., problems relating to ethics, compliance, personnel resources, or competency). These results are robust when using an entropy balance matched sample or excluding regulated industries. Finally, we find that a firm's ineffective internal control significantly predicts its future employee turnover, especially the turnover of male rank-and-file accountants.

One possible alternative explanation for our results is that women prefer to join firms with cultures that correlate with a lower likelihood of internal control weaknesses. This alternative explanation is inconsistent with our finding that the negative relation is strong when female accountants are underrepresented but plateaus when gender diversity exceeds parity. If female accountants prefer to join firms that are less likely to suffer from internal control weaknesses, we would expect the negative relation to hold when the firm exceeds gender parity. Nevertheless, to mitigate this concern, we control for the percentage of female employees across the entire firm, and we find that this control variable is not associated with the likelihood of internal control weaknesses. If our main result is driven by the firm culture, we would expect a similar relation for the gender of all employees and not just limited to accounting employees.

A second alternative explanation is that female accountants might be more qualified than male accountants to do the job. For example, it could be the case that female accountants are more experienced or better educated than male accountants. However, there is little reason to believe that this potential correlated omitted variable has an effect when female accountants are 
underrepresented but does not when gender diversity exceeds parity. ${ }^{6}$ While we cannot completely rule out these alternative explanations, we believe that our controls and our piecewise regression analyses render these explanations less plausible.

Our study has implications for academics, managers and regulators. To the best of our knowledge, we are the first to provide large-sample archival evidence on whether gender plays a role in accounting practices at the rank-and-file employee level. Prior studies largely focus on the effects of female employees at the top level of the corporate hierarchy. It is an open question whether there are distinct female effects at the rank-and-file employee level. We find that the percentage of female accounting employees is negatively associated with the likelihood of internal control weaknesses. Furthermore, we find that these female effects are stronger when gender diversity is below parity, and attenuate as gender diversity exceeds parity, consistent with prior studies in management showing that the effect of gender diversity peaks around parity (e.g., Frink et al. 2003; Ali et al. 2011).

Second, our study contributes to the literature on the determinants of internal control quality. The traditional framework of internal control weaknesses focuses on business fundamentals (e.g., complexity, changes in businesses, financial resources, accounting application risks) and the external monitoring environment (e.g., auditor scrutiny, regulator intervention, investor intervention, litigation) (e.g., Ashbaugh-Skaife et al. 2007; Doyle et al. 2007). Emerging studies

\footnotetext{
${ }^{6}$ Anecdotal evidence suggests that female accountants have similar education and qualification as male accountants. For instance, the Association of International Certified Professional Accountants (AICPA) shows that the proportion of female accounting students is 49\% (50\%) at the bachelor's (master's) level in 2017-2018 (see https://www.aicpa.org/content/dam/aicpa/interestareas/accountingeducation/newsandpublications/downloadabledoc uments/2019-trends-report.pdf). The PCAOB reports that women represent about 50\% of new certified public accountants (CPAs) in the accounting profession for the past 20 years (see https://pcaobus.org/News/Speech/Pages/03132014_Washington_Women.aspx)
} 
suggest that employees comprise another important determinant for internal control quality. ${ }^{7}$ For instance, using survey data collected by the Institute of Internal Auditors on around 200 firms, Lin et al. (2011) find that the likelihood of having internal control weaknesses is associated with various attributes and activities of a firm's internal audit function. Call et al. (2017) show that the workforce education level at a firm's headquarters location is positively associated with internal control quality. Guo et al. (2016) provide evidence that firm-wide employee-friendly policies are associated with a lower propensity for ineffective internal control. Using unique data on rank-andfile accounting employees, our study points out that internal accountants' gender is an important determinant of internal control quality.

Finally, our study has policy implications. The SEC recently proposed a plan to modernize firm disclosure by expanding the limited disclosure requirements for human capital (SEC 2019). ${ }^{8}$ In a follow-up comment letter, the Human Capital Management Coalition which represents a group of influential institutional investors advocates that all SEC registrants should be required to disclose the workforce diversity data including gender diversity across different levels of seniority. ${ }^{9}$ Our results suggest that disclosure of the percentage of female internal accounting employees can help inform investors and regulators about internal control quality. It is possible that the percentage of female employees in other positions also affects their related corporate outcomes. ${ }^{10}$ As our study

\footnotetext{
${ }^{7}$ A few other studies have examined the effect of accounting employees on financial reporting quality. For instance, in a sample of around 200 firms, Prawitt et al. (2009) find a negative association between the quality of internal audit function and earnings management. Using data on accounting employees in S\&P 1500 companies who have previously worked in public accounting firms, Bird et al. (2015) find accounting employees who have previously worked in the current company's audit firms are negatively associated with financial reporting quality. ${ }^{8}$ Currently, firms only need to disclose the number of employees at the end of the year in 10-K filings and the median employee pay. In Feb. 6, 2019, the SEC issued guidance on board diversity disclosure, including gender (see the answer to question 116.11 at https://www.sec.gov/divisions/corpfin/guidance/regs-kinterp.htm).

${ }^{9}$ See https://www.sec.gov/comments/s7-11-19/s71119-6322887-194462.pdf

${ }^{10}$ For instance, over 800 CEOs have signed a pledge to advance diversity and inclusion within the workplace. The CEO pledge says "Simply put, organizations with diverse teams perform better." (see https://www.ceoaction.com/pledge/ceo-pledge/).
} 
highlights the importance of gender diversity at the employee level, the SEC should consider issuing similar guidance on the disclosure of diversity by position. ${ }^{11,12}$

\section{Data and Sample}

\subsection{Data Sources}

We obtain proprietary data on rank-and-file accounting employees for public firms listed in the U.S. from a third-party company that gathers employee information from public sources and compiles the data monthly at the firm level. We average the monthly data to form our annual data on headcounts (i.e., the number of employees who worked for a firm at any point during the year) for both female and male rank-and-file accounting employees.

Our sample begins with 26,361 firm-year observations that have both nonmissing accounting employees tracked by the third-party company and one-year-ahead internal control information under Section 404 ("Management Assessment of Internal Controls") of the Sarbanes-Oxley Act (SOX) retrieved from Audit Analytics during the fiscal years 2007-2017. We further require nonmissing control variables in the regression models of internal control weaknesses, which results in our main sample of 23,542 firm-years. ${ }^{13}$

\subsection{Descriptive Evidence}

\footnotetext{
${ }^{11}$ Some firms already disclose such information. For example, Microsoft breaks down its workforce by position and gender (see https://query.prod.cms.rt.microsoft.com/cms/api/am/binary/RE4aqv1).

${ }^{12}$ As a direct comment to the SEC to modernize firm disclosure, the California Public Employees' Retirement System (CalPERS) recommended human capital metrics that should be disclosed by all companies about their employees, including diversity (see https://www.irmagazine.com/regulation/calpers-raises-materiality-concerns-over-secdisclosure-reforms).

${ }^{13}$ In the analysis of employee-related internal control weaknesses (ICW_EMP), the sample size is reduced to 22,837 because we require nonmissing $I C W_{-} E M P$. In the analysis on employee turnover, the sample size is reduced to 21,565 because we require nonmissing values in the one-year-ahead turnover measures and market-related variables (stock returns and market-to-book ratio). In robustness tests on non-regulated industries, the sample size is reduced since we exclude firms from financial or utilities industries. In the test on the material weaknesses of disclosure controls under SOX $302(D C W)$, we omit 32 firm-years due to missing values in $D C W$.
} 
Table 1, Panel A provides the average percentage of female employees per year for different positions. ${ }^{14}$ The percentages of both female accountants and female non-accounting employees remain relatively stable over our sample period (about $51 \%$ and $42 \%$, respectively). A higher proportion of female accountants (compared to female non-accountants) is consistent with the popularity of accounting degrees among female students. Consistent with prior research, female CEOs and CFOs are rare, and the percentage of female directors is low. However, there is an obvious upward trend in the proportions of female CEOs, CFOs, and directors over our sample period.

Table 1, Panel B shows the percentage of female employees for each major industry sector averaged across all years in our sample. We observe the highest proportion of female rank-andfile accounting employees in the wholesale and retail sector and the lowest proportion in the manufacturing sector. They are consistent with Herring's (2009) data at the work establishment level for the period 1996-1997.

Figure 1, Panels A and B depict the frequency of female accountants and female nonaccountants for each five-percentage point interval. The overall distribution of female accountants approximates a standard normal distribution except for the abnormalities at the two extreme tails (i.e., unexpectedly high frequencies of firms with only female or only male accountants). While it is unclear why "single-sex" teams exist, we control for their potential effects in our regression analyses by including the indicator of the observations in the tails.

Table 2, Panel A presents descriptive statistics for the main variables of interest. Notably, the average number of accounting employees in our sample is 105 , but there is considerable variation with a median of 23 . The average (one-year-ahead) annual turnover rate for accounting employees

\footnotetext{
${ }^{14}$ The medians of female rank-and-file employees are very similar to the reported means.
} 
is $15 \% .{ }^{15}$ The average frequency of (one-year-ahead) internal control weaknesses under SOX 404 $(I C W)$ is $6 \%$, while the average frequency of employee-specific internal control weaknesses $\left(I C W \_E M P\right)$ is $3 \%$, which is comparable to prior research. ${ }^{16}$

Table 2, Panel B presents Pearson correlations among female employee variables. The correlation between the proportion of female accountants (\%Female_Acct) and the proportion of female non-accountants (\%Female_NonAcct) is 0.174. We observe a similar correlation between \%Female_NonAcct and \%Female_Director (0.187). These correlations highlight the importance of using \%Female_NonAcct to control for the potential effects of a firm-wide femalefriendly culture on internal control quality. On the other hand, the correlations between \%Female_Acct and both \%Female_CEO/CFO and \%Female_Director are less than $10 \%$.

\section{Empirical Results}

\subsection{Baseline Regression Results}

Table 3 reports the results of logistic regressions. The dependent variables for Columns 1 and 2 are one-year-ahead internal control weaknesses $(I C W)$. We find that \%Female_Acct is statistically significant at the two-tailed $1 \%$ level in all specifications, and the log odds of having internal control weaknesses decreases by 0.503 when the proportion of female accountants increases from 0 to 1 . We further calculate that the average predicated probability of $I C W$ decreases by $2.5 \%$ when $\%$ Female_Acct changes from the lowest level of 0 to the highest level of 1 , which

\footnotetext{
${ }^{15}$ This turnover rate is comparable to the average turnover rate for all industries in the U.S. According to Compensation Force, the total employee turnover in the U.S. in 2016 was 17.8\%. (see https://www.compensationforce.com/2017/04/2016-turnover-rates-by-industry.html).

${ }^{16}$ Prior studies (e.g., Ashbaugh-Skaife et al. 2007; Doyle et al. 2007; Skaife et al. 2013; Guo et al. 2016) appear to show a slightly higher likelihood of internal control weaknesses because their samples include earlier years (especially the year 2004). For instance, Skaife et al. (2013) (Table 1, Panel C) shows that the probability of internal control weaknesses decreases from $17.3 \%$ in 2004 to $3.2 \%$ in 2008.
} 
is economically significant given that the mean of $I C W$ is only $6 \%$. The estimated marginal effect of \%Female_Acct is comparable to that of \%Female_CEO/CFO.

Columns 3 and 4 show the results for the dependent variable of employee-specific internal control weaknesses $\left(I C W \_E M P\right)$. This indicator variable is set to one if the reasons for ineffective internal controls include "ethical or compliance problems with personnel" or "accounting personnel resources, competency, and training" as classified by Audit Analytics, ${ }^{17}$ and zero if the firm has no internal control weaknesses for the year. We find negative associations between \%Female_Acct and ICW_EMP, consistent with female effects mitigating employeespecific internal control weaknesses. Untabulated results indicate insignificant results when we use non-employee-related internal control weaknesses as the dependent variable.

The percentage of female non-accountants (\%Female_NonAcct) is insignificant in all regressions. Thus, the female-friendly corporate culture does not affect internal control quality. This mitigates the concern that the results for \%Female_Acct are driven by a female-friendly corporate culture. We also find that \%Female_CEO/CFO is negatively associated with $I C W$, which complements prior studies on how gender diversity among top-level executives has a positive effect on accounting quality (e.g., Francis et al. 2015). On the other hand, \%Female_CEO/CFO is not associated with $I C W \_E M P$. This suggests that female effects at the top executive level are not an important determinant of employee-specific internal control weaknesses. Furthermore, we find no significant association between \%Female_Director and one-

\footnotetext{
${ }^{17}$ Audit Analytics provides detailed codes that classify the reasons of internal control weaknesses. Consistent with Guo et al. (2016), we use code 21 ("ethical or compliance problems with personnel") and code 44 ("accounting personnel resources, competency, and training") to identify material weaknesses that are more related to rank-and-file employees. Non-employee-specific reasons include others such as code 7 ("Management/board/audit committee investigations") and code 13 ("Senior management competency, tone, reliability issues"). We acknowledge that this classification may be noisy or incomplete as most internal control weaknesses have at least some relation to employees. Untabulated results suggest the difference between employee-specific ICW and non-employee-specific ICW is insignificant.
} 
year-ahead $I C W$ or $I C W \_E M P$. The coefficients on \%Female_Acct remain significant at the $1 \%$ level after controlling for \%Female_CEO/CFO and \%Female_Director. This indicates that female effects at the rank-and-file employee level are distinct from the female effects at the top executive or director level.

The estimated coefficients for our control variables are similar to prior studies (e.g., AshbaughSkaife et al. 2007; Doyle et al. 2007; Guo et al. 2016). We find that larger and older firms are less likely to have internal control weaknesses, while growth and loss firms are more likely to have internal control weaknesses. Firms with higher debt, higher profit volatility, and more complex operating activities (e.g., foreign operations, diversified operations, mergers and acquisitions) are also more likely to have internal control weaknesses. Regarding proxies for monitoring, we find that the percentage of independent directors, whether the firm employs a Big Four auditor, the number of analysts, and the percentage of institutional ownership are negatively associated with one-year-ahead $I C W$.

\subsection{Piecewise Regression Results}

Does the negative coefficient on \%Female_Acct suggest that, ceteris paribus, a higher percentage of female accountants always improves the quality of internal control procedures? If this were the case, it might be optimal for firms to increase the percentage of female accountants to $100 \%$, especially given the relatively lower costs of female labor. This increase would be consistent with the notion that female accountants tend to be more trustworthy, more compliant, more risk averse, and less overconfident. On the other hand, one might expect that a 50\% female ratio might be optimal (e.g., Frink et al. 2003; Ali et al. 2011), suggesting a nonlinear relation between \%Female_Acct and the likelihood of internal control weaknesses. 
To capture the possible presence of the curvilinear diversity effect, we estimate a piecewise logistic regression using the midpoint of \%Female_Acct (i.e., 50\%) as the breakpoint, since gender diversity is maximized at the midpoint. Specifically, we follow prior studies (e.g., Morck et al. 1988; Cho 1998) to construct the variables \%Female_Acct_Below50 and \%Female_Acct_Above50, which allows us to detect potential shifts in the relation below and above the midpoint in the piecewise regressions below.

$$
\begin{aligned}
\% \text { Female_Acct_Below } 50 & =\% \text { Female_Acct if } 0 \leqslant \% \text { Female_Acct } \leqslant 0.5, \\
& =0.5 \text { if } 0.5<\% \text { Female_Acct } \leqslant 1 ; \\
\% \text { Female_Acct_Above } 50 & =0 \text { if } \% \text { Female_Acct } \leqslant 0.5, \\
& =(\% \text { Female_Acct }-0.5) \text { if } 0.5<\% \text { Female_Acct } \leqslant 1 .
\end{aligned}
$$

Table 4 reports the results of the piecewise regressions. Columns 1 and 2 (Columns 3 and 4) show significant negative coefficients for \%Female_Acct_Below ${ }_{50}$ for ICW $\left(I C W_{-} E M P\right)$, and the estimated coefficients are twice as large as those reported for \%Female_Acct in Table 3. In contrast, the coefficients for \%Female_Acct_Aboveso are insignificant. These results suggest a negative relation between \%Female_Acct and one-year-ahead internal control weaknesses in the $0 \%$ and $50 \%$ range, and there is no relation when \%Female_Acct exceeds 50\%. One interpretation of these results is that the three distinct female channels (i.e., ethicality, risk aversion, and diversity) work in the same direction when female accountants are underrepresented, but the diversity channel has a countervailing effect when the proportion of female accountants exceeds the midpoint. ${ }^{18}$

\footnotetext{
${ }^{18}$ In robustness tests of nonlinearity, we explore alternative values of $\%$ Female_Acct $(=40 \%$ or $60 \%)$ as the breakpoint in the piecewise regressions. We also use multiple breakpoints, or include a squared term. The main takeaway of the curvilinear relation remains the same. That is, \%Female_Acct is negatively associated with $I C W$ when female accountants are underrepresented, but this negative association attenuates when gender diversity exceeds gender parity.
} 
Figure 2, Panels A and B show the relation between \%Female_Acct and the predicted values for one-year-ahead $I C W$ and $I C W_{-} E M P$, respectively, implied by the piecewise regressions while holding other control variables at their respective means. Consistent with the results shown in Table 4, the predicted likelihood of internal control weaknesses decreases as \%Female_Acct increases from $0 \%$ to the midpoint (i.e., when female accountants are underrepresented), but attenuates when \%Female_Acct exceeds the midpoint.

\subsection{Entropy Balance Matching (EBM) Analysis}

Potential concerns regarding our main analyses are (a) that firms with a higher percentage of female accountants are fundamentally different from those with a lower percentage of female accountants (e.g., different in terms of corporate culture or access to the female labor pool) and (b) that our covariates (e.g., \%Female_NonAcct) do not completely eliminate uncontrolled effects in the logistic regression.

To address these concerns, we employ the entropy balance matching (EBM) method, which effectively recalibrates the observation weights by adjusting for systematic and random differences in the covariates (i.e., covariate balance). Specifically, we create two subsamples according to the median of \%Female_Acct, then run a determinant model of the membership in the subsample of above-median firms $($ High_\%Female_Acct $=1$ when $\%$ Female_Acct is above the sample median and 0 otherwise). The EBM algorithm recalibrates the observation weights to obtain insignificant differences in the covariates between these two subsamples. Table 5, Panel A shows that the EBM effectively achieves covariate balance.

Table 5, Panel B reports the logistic regression results when we use the EBM sample. The estimated coefficients and associated $z$-statistics are very similar to those reported in Table 3 and Table 4, suggesting that the differences in the covariates should not cause concerns in our setting. 


\subsection{Employee Turnover Analysis}

As an additional analysis, we examine the potential consequences of internal control weaknesses on rank-and-file accounting employees. Specifically, we regress one-year-ahead internal accountant turnover rates on the indicator of internal control weaknesses. Table 6 shows positive associations between the indicator of internal control weaknesses and one-year-ahead turnover rates for accounting employees. This suggests that internal control weaknesses have real consequences on internal accountants, after controlling for other determinants of turnover rates as well as all the variables in our internal control model.

Importantly, we find that the effect of internal control weaknesses is significant only for male accountants, especially for the subsample in which the percentage of female accounting employees is below the midpoint (i.e., female accountants are underrepresented). We cannot distinguish between voluntary and non-voluntary turnover, but the negative nature of the event (i.e., internal control weakness) suggests that the turnover associated with the event is likely non-voluntary. This result is consistent with the higher likelihood of male accountants being laid off after the event compared to female accountants.

Coefficients for other turnover determinants are consistent with prior studies. Specifically, coefficients on Return, ROA are negative, while the coefficient on Loss is positive, consistent with better performance leading to lower employee turnover.

\subsection{Robustness Tests}

\subsubsection{Excluding regulated industries}

To mitigate the potential effects of regulations on internal control quality, we rerun our analyses after excluding utilities firms (SICs between 4900 and 4999) and financial industries (SICs between 6000 and 6999). Table 7, Panel A shows that \%Female_Acct remains negatively 
associated with the likelihood of one-year-ahead internal control weaknesses, and this association is concentrated for \%Female_Acct below the midpoint. This is consistent with our main results.

\subsubsection{Material weaknesses under SOX 302}

In our main analyses, we focus on internal control weaknesses under SOX 404, which requires management to attest to the effectiveness of their internal controls over financial reporting (ICFR) (e.g., Skaife et al. 2013; Guo et al. 2016; Call et al. 2017). On the other hand, SOX 302, which targets disclosure controls and procedures (DCP), requires management to certify that all material internal control problems are disclosed both quarterly and annually. ${ }^{19}$ In this robustness test, we examine whether the effects of female accounting employees also apply to disclosure control quality under SOX 302.

Table 7, Panel B, Columns 1 and 2 show that \%Female_Acct is negatively associated with the likelihood of disclosure control weaknesses $(D C W)$, which equals 1 if at least one material weakness of disclosure controls (under SOX 302) is identified in any of the 10-Q or 10-K filings during the year, and 0 otherwise. This association is also nonlinear, as the effect of female accounting employees is significantly negative when female accountants are underrepresented, but the effect becomes insignificant when \%Female_Acct exceeds the midpoint. Columns 3 and 4 show that the results are similar for material weaknesses under both SOX 404 and 302 (i.e., both $I C W$ and $D C W$ equal 1). Thus, the negative association between the percentage of female accounting employees and future material weaknesses continues to hold for disclosure controls and procedures under SOX 302.

\footnotetext{
19 To some extent, SOX 302 is broader than SOX 404 because DCP under SOX 302 may be ineffective for reasons unrelated to ICFR under SOX 404, such as when a company has failed to file reports on a timely basis (see Item 307 of Regulation S-K).
} 


\section{Conclusions}

This study examines the effects of female rank-and-file accounting employees on firms' internal control quality. We use rank-and-file employee data from a third-party company that continuously tracks a large number of publicly available online employee profiles. We find a curvilinear, negative relation between the percentage of female accounting employees and the likelihood of internal control weaknesses. The association between \%Female_Acct and $I C W\left(\right.$ or $\left.I C W \_E M P\right)$ is negative and significant when female accountants are underrepresented, while this association attenuates when gender diversity exceeds gender parity. We also find that the indicator of internal control weaknesses predicts the future turnover of rank-and-file accountants, especially the male accounting employees.

Our study provides large-sample evidence on the role that gender plays in a firm's accounting environment at the rank-and-file employee level. Our results underscore the importance of the proportion of female internal accountants in determining internal control quality. We also contribute to the emerging literature on the effect of employees on firms' accounting practices.

With our granular data on rank-and-file employees, we envision promising future research venues. For example, employing a diverse workforce might be associated with a firm's investment strategy and risk profile. Similarly, the gender composition of various positions within a firm might affect corporate outcomes related to those positions. For example, the gender composition of taxrelated positions may play a role in determining the tax strategy of a firm, while the percentage of female engineers may affect a firm's technological innovation. 


\section{References}

Adams RB, Ferreira D (2009) Women in the boardroom and their impact on governance and performance. Journal of Financial Economics. 94(2):291-309.

Adhikari BK, Agrawal A, Malm J (2019) Do women managers keep firms out of trouble? Evidence from corporate litigation and policies. Journal of Accounting and Economics. 67(1):202-225.

Agnew JR, Anderson LR, Gerlach JR, Szykman LR (2008) Who chooses annuities? An experimental investigation of the role of gender, framing, and defaults. American Economic Review. 98(2):418-422.

Agnew J, Balduzzi P, Sunden A (2003) Portfolio choice and trading in a large 401 (k) plan. American Economic Review. 93(1):193-215.

Ali M, Kulik CT, Metz I (2011) The gender diversity-performance relationship in services and manufacturing organizations. The International Journal of Human Resource Management. 22(07):1464-1485.

Ashbaugh-Skaife H, Collins DW, Kinney Jr WR (2007) The discovery and reporting of internal control deficiencies before SOX-mandated audits. Journal of Accounting and Economics. 44(1-2):166-192.

Barber BM, Odean T (2001) Boys will be boys: Gender, overconfidence, and common stock investment. Quarterly Journal of Economics. 116(1):261-292.

Barnett T, Brown G, Bass K (1994) The ethical judgments of college students regarding business issues. Journal of Education for Business. 69(6):333-338.

Bernardi RA, Arnold Sr DF (1997) An examination of moral development within public accounting by gender, staff level, and firm. Contemporary Accounting Research 14(4):653668.

Bird A, Ho N, Li C, Ruchti T (2015) That's what friends are for: Audit quality and accounting employee affiliations with audit firms. Working Paper.

Bureau of Labor Statistics (2019) Table 11: Employed persons by detailed occupation, sex, race, and Hispanic or Latino ethnicity. Current Population Survey, Household Data Annual Averages. U.S. U.S Department of Labor, Washington, DC.

Bureau of Labor Statistics (2019) Table 39: Median weekly earnings of full-time wage and salary workers by detailed occupation and sex. Current Population Survey, Household Data Annual Averages. U.S. U.S Department of Labor, Washington, DC.

Byrnes JP, Miller DC, Schafer WD (1999) Gender differences in risk taking: A meta-analysis. Psychological Bulletin. 125(3):367-383.

Call AC, Campbell JL, Dhaliwal DS, Moon Jr JR (2017) Employee quality and financial reporting outcomes. Journal of Accounting and Economics. 64(1):123-149.

Campbell K, Mínguez-Vera A (2008) Gender diversity in the boardroom and firm financial performance. Journal of Business Ethics. 83(3):435-451.

Carlson R (1972) Understanding women: Implications for personality theory and research. Journal of Social Issues. 28(2):17-32. 
Cho MH (1998) Ownership structure, investment, and the corporate value: an empirical analysis. Journal of Financial Economics. 47(1):103-121.

Cumming D, Leung TY, Rui O (2015) Gender diversity and securities fraud. Academy of Management Journal. 58(5):1572-1593.

Doyle J, Ge W, McVay S (2007) Determinants of weaknesses in internal control over financial reporting. Journal of Accounting and Economics. 44(1-2):193-223.

Erhardt NL, Werbel JD, Shrader CB (2003) Board of director diversity and firm financial performance. Corporate Governance: An International Review. 11(2):102-111.

Francis B, Hasan I, Park JC, Wu Q (2015) Gender differences in financial reporting decision making: Evidence from accounting conservatism. Contemporary Accounting Research. 32(3):1285-1318.

Frink DD, Robinson RK, Reithel B, Arthur MM, Ammeter AP, Ferris GR, Kaplan DM, Morrisette HS (2003) Gender demography and organization performance: A two-study investigation with convergence. Group \& Organization Management. 28(1):127-147.

Ge W, McVay S (2005) The disclosure of material weaknesses in internal control after the Sarbanes-Oxley Act. Accounting Horizons. 19(3):137-158.

Gul FA, Srinidhi B, Ng AC (2011) Does board gender diversity improve the informativeness of stock prices? Journal of Accounting and Economics. 51(3):314-338.

Guo J, Huang P, Zhang Y, Zhou N (2016) The effect of employee treatment policies on internal control weaknesses and financial restatements. The Accounting Review. 91(4):1167-1194.

Hambrick DC, Mason PA (1984) Upper echelons: The organization as a reflection of its top managers. Academy of Management Review. 9(2):193-206.

Herring C (2009) Does diversity pay?: Race, gender, and the business case for diversity. American Sociological Review. 74(2):208-224.

Hoever IJ, Van Knippenberg D, Van Ginkel WP, Barkema HG (2012) Fostering team creativity: Perspective taking as key to unlocking diversity's potential. Journal of Applied Psychology. 97(5):982-996.

Ibrahim N, Angelidis J, Tomic IM (2009) Managers' attitudes toward codes of ethics: Are there gender differences? Journal of Business Ethics. 90(3):343-353.

Jianakoplos NA, Bernasek A (1998) Are women more risk averse? Economic inquiry. 36(4):620630.

Lai KM, Srinidhi B, Gul FA, Tsui JS (2017) Board gender diversity, auditor fees, and auditor choice. Contemporary Accounting Research. 34(3):1681-1714.

Lin S, Pizzini M, Vargus M, Bardhan IR (2011) The role of the internal audit function in the disclosure of material weaknesses. The Accounting Review. 86(1):287-323.

Mason ES, Mudrack PE (1996) Gender and ethical orientation: A test of gender and occupational socialization theories. Journal of Business Ethics. 15(6):599-604.

Matsa DA, Miller AR (2011) Chipping away at the glass ceiling: Gender spillovers in corporate leadership. American Economic Review. 101(3):635-39. 
Morck R, Shleifer A, Vishny RW (1988) Management ownership and market valuation: An empirical analysis. Journal of Financial Economics. 20:293-315.

Odean T (1998) Volume, volatility, price, and profit when all traders are above average. Journal of Finance. 53(6):1887-1934.

Olsen RA, Cox CM (2001) The influence of gender on the perception and response to investment risk: The case of professional investors. Journal of Psychology and Financial Markets. 2(1):29-36.

Powell M, Ansic D (1997) Gender differences in risk behavior in financial decision-making: An experimental analysis. Journal of Economic Psychology. 18(6):605-628.

Prawitt DF, Smith JL, Wood DA (2009) Internal audit quality and earnings management. The Accounting Review. 84(4): 1255-1280.

Public Company Accounting Oversight Board (PCAOB) (2004) Auditing standard No. 2: An audit of internal control over financial reporting performed in conjunction with an audit of financial statements. Public Company Accounting Oversight Board, Washington, DC.

Ruegger D, King EW (1992) A study of the effect of age and gender upon student business ethics. Journal of Business Ethics. 11(3):179-186.

Securities and Exchange Commission (SEC) (2007) Commission guidance regarding management's report on internal control over financial reporting under section 13(a) or 15(d) of the Securities Exchange Act of 1934. U.S. Securities and Exchange Commission, Washington, DC.

Securities and Exchange Commission (SEC) (2019) Modernization of regulation S-K items 101, 103, and 105. U.S. Securities and Exchange Commission, Washington, DC.

Skaife HA, Veenman D, Wangerin D (2013) Internal control over financial reporting and managerial rent extraction: Evidence from the profitability of insider trading. Journal of Accounting and Economics. 55(1):91-110.

Srinidhi B, Gul FA, Tsui J (2011) Female directors and earnings quality. Contemporary Accounting Research. 28(5):1610-1644.

Sunden AE, Surette BJ (1998) Gender differences in the allocation of assets in retirement savings plans. American Economic Review. 88(2):207-211. 
Appendix. Variable Definitions

\begin{tabular}{|c|c|}
\hline$\%$ Female_Acct & $\begin{array}{l}\text { Percentage of female accounting-related employees over the total number of } \\
\text { accounting-related employees in the firm }\end{array}$ \\
\hline \%Female_NonAcct & Percentage of female employees (other than accounting-related employees) in the firm \\
\hline \%Female_CEO/CFO & $\begin{array}{l}\text { Percentage of female CEOs or CFOs over the total number of CEOs or CFOs in the } \\
\text { firm }\end{array}$ \\
\hline \%Female_Director & Percentage of female directors over the total number of directors in the firm \\
\hline Tail(\%Female_Acct) & Dummy variable that equals 1 if \%Female_Acct $<0.05$ or $>0.95$ \\
\hline Size & Firm size, the natural logarithm of total assets \\
\hline Age & Firm age, measured as the number of years in Compustat \\
\hline Growth & Sales growth, annual percentage increase in sales \\
\hline ROA & ROA, income before extraordinary items scaled by total assets (ib $\div$ at) \\
\hline Loss & Loss indicator, 1 if net loss \\
\hline Leverage & Book leverage, total debt scaled by total assets $((\mathrm{dltt}-\mathrm{dlc}) \div \mathrm{at})$ \\
\hline Zscore & $\begin{array}{l}\text { Altman's Z-score computed as } 1.2 \times(\text { act }- \text { lct }) \div \text { at }+1.4 \times \text { re } \div \text { at }+3.3 \times \text { oiadp } \div \text { at }+ \\
0.6 \times(\text { csho } \times \text { prcc_f }+ \text { pstk }) \div \text { at }+0.999 \times \text { sale } \div \text { at }\end{array}$ \\
\hline VolROA & $\begin{array}{l}\text { Volatility of ROA over the firm-specific past 7-year rolling window (requiring at least } 3 \\
\text { nonmissing years) }\end{array}$ \\
\hline Foreign & Dummy variable that equals1 if the firm has foreign transactions \\
\hline Diversification & Dummy variable that equals1 if the firm has two or more industry segments \\
\hline Restruct & Dummy variable that equals1 if the firm has restructuring activities \\
\hline M\&A & Dummy variable that equals 1 if the firm has M\&A activities \\
\hline \%IndDirector & Percentage of independent directors \\
\hline Big4Auditor & Dummy variable that equals 1 if the firm's auditor is a Big Four auditor \\
\hline Analyst & Log(Number of analysts) \\
\hline \%InstOwnership & Percentage of institutional ownership \\
\hline Return & Annual raw returns \\
\hline $\mathrm{MB}$ & Market-to-Book ratio computed as $($ csho $\times$ prcc_f $) \div$ ceq \\
\hline ICW & $\begin{array}{l}\text { Internal control weakness indicator that equals } 1 \text { if at least one material weakness under } \\
\text { SOX } 404 \text { is reported and } 0 \text { otherwise }\end{array}$ \\
\hline ICW_EMP & $\begin{array}{l}\text { Employee-specific ICW that equals1 if at least one employee-specific material } \\
\text { weakness under SOX } 404 \text { is reported, and } 0 \text { if there is no internal control weakness in } \\
\text { the year. An internal control weakness is defined to be employee-specific if its reasons } \\
\text { include Code } 21 \text { ("IC - Ethical or compliance issues with personnel") or Code } 44 \text { ("IC - } \\
\text { Accounting personnel resources, competency/training") as classified by Audit Analytics }\end{array}$ \\
\hline $\mathrm{DCW}$ & $\begin{array}{l}\text { Disclosure control weakness indicator that equals1 if at least one material weakness is } \\
\text { reported under SOX } 302 \text { (in any of the four quarters in the year), and } 0 \text { otherwise }\end{array}$ \\
\hline ICW_DCW & $\begin{array}{l}\text { Internal control and disclosure control weakness indicator that equals } 1 \text { if } I C W=1 \text { and } \\
D C W=1 \text {, and } 0 \text { otherwise }\end{array}$ \\
\hline Turnover_Overall & $\begin{array}{l}\text { Overall turnover of accountants: the number of accounting employees leaving during } \\
\text { the year } \div \text { number of accounting employees who worked at any point during the year }\end{array}$ \\
\hline Turnover_Female & $\begin{array}{l}\text { Turnover of female accountants: the number of female accountants leaving in the year } \div \\
\text { number of female accountants who worked at any point during the year }\end{array}$ \\
\hline Turnover_Male & $\begin{array}{l}\text { Turnover of male accountants: the number of male accountants leaving in the year } \div \\
\text { number of male accountants who worked at any point during the year }\end{array}$ \\
\hline
\end{tabular}


Figure 1: Distribution of the Percentage of Female Employees

This figure shows the frequency of the mean values for \%Female_Acct and \%Female_NonAcct over 20 bins in Panels A and B, respectively.

Panel A: Female Accounting Employees

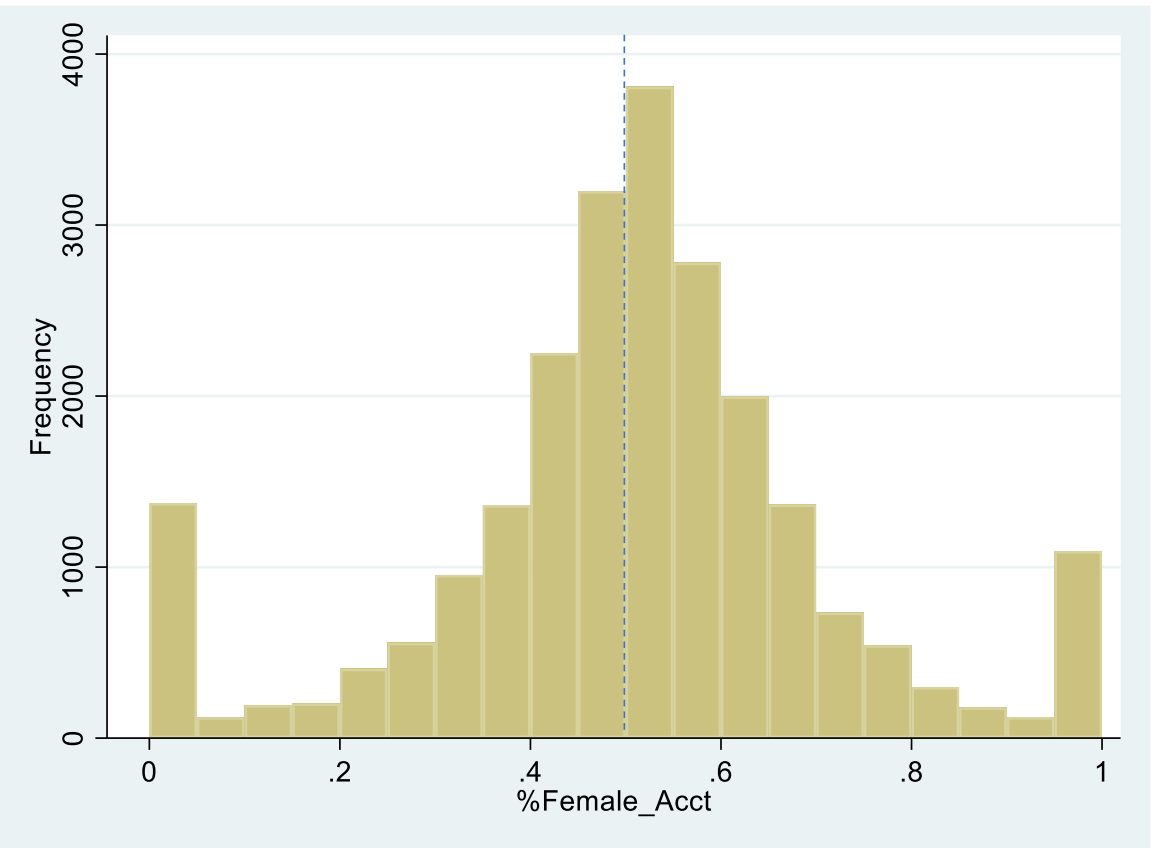

Panel B: Female Non-Accounting Employees

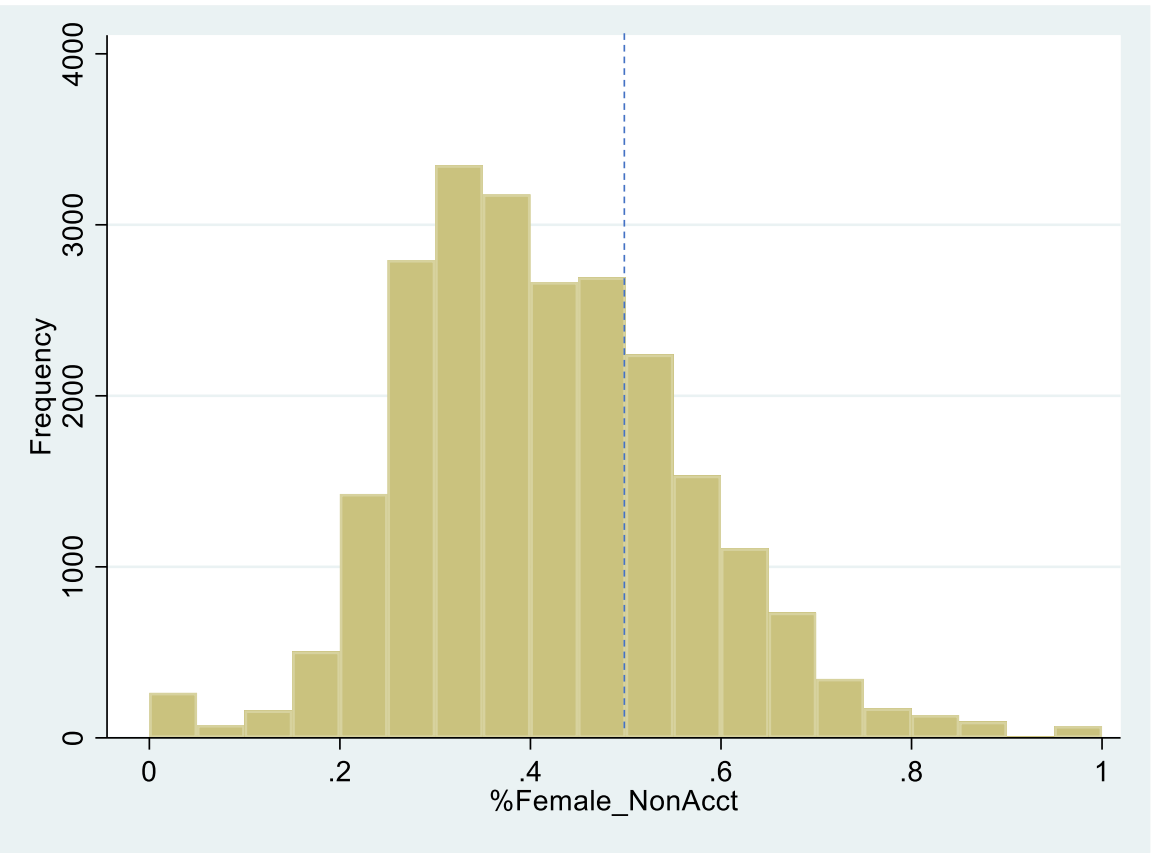




\section{Figure 2: Piecewise Relations}

This figure shows the relation between \%Female_Acct and the predicted probability of one-year-ahead internal control weaknesses $(I C W)$ and employee-specific internal control weaknesses $\left(I C W_{-} E M P\right)$ in Panels A and $\mathrm{B}$, respectively, implied by the piecewise logistic regression with the midpoint of \%Female_Acct as the breakpoint, holding all other control variables at their respective means.

Panel A: Piecewise Relation between one-year-ahead ICW and \%Female_Acct

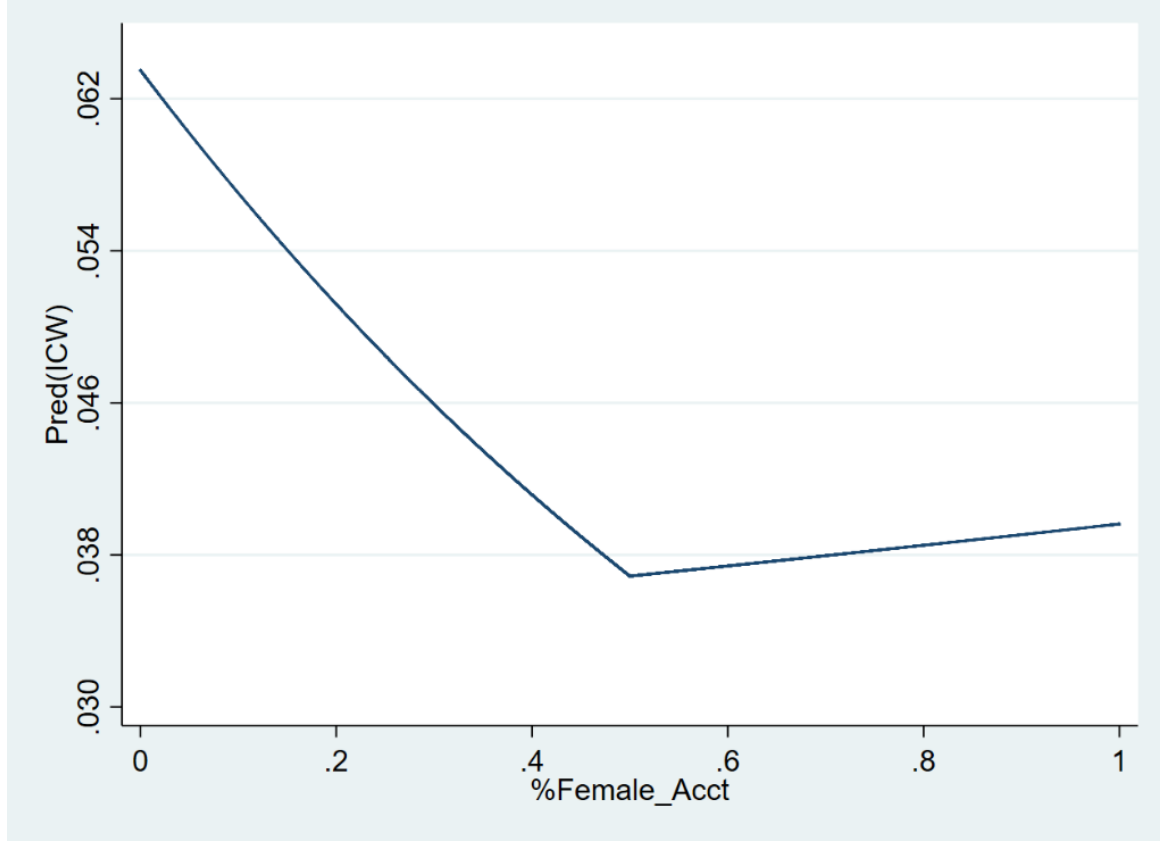

Panel A: Piecewise Relation between one-year-ahead $I C W \_E M P$ and $\%$ Female_Acct

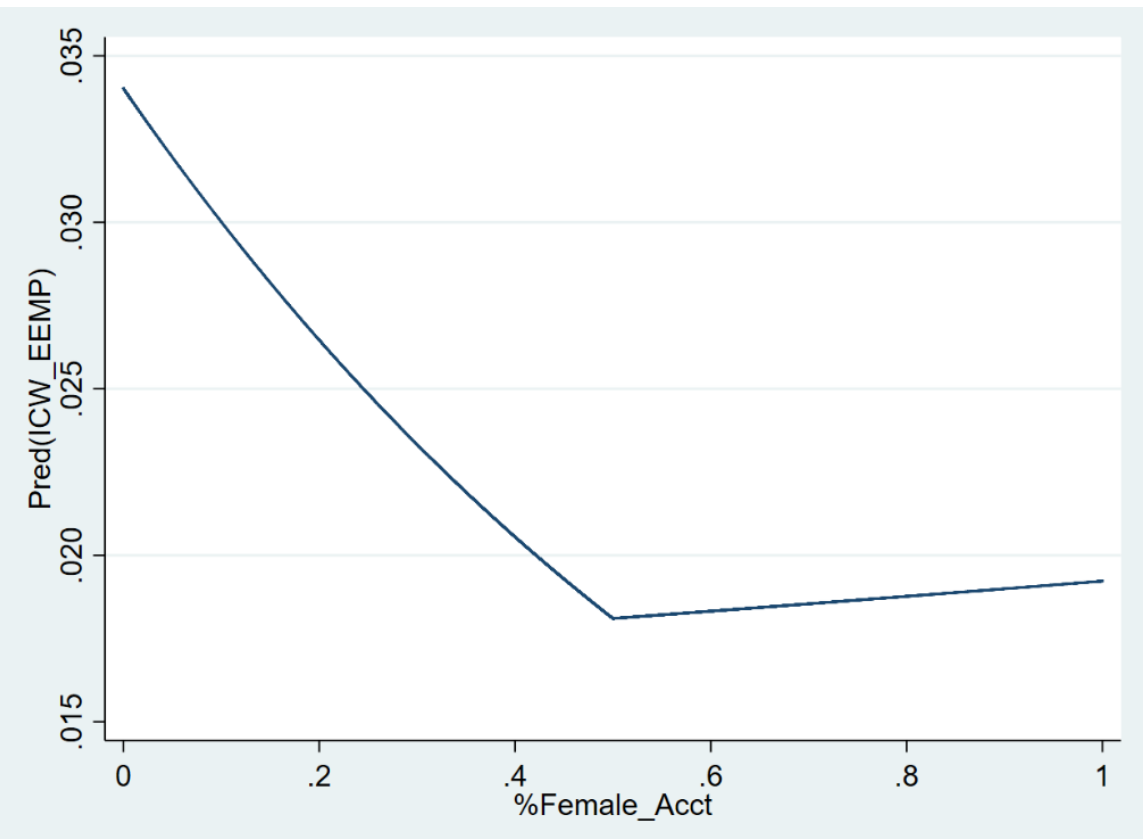


Table 1. Distribution of the Female Percentage for Employees, Top Executives, and Directors

This table reports the distribution of the average female percentage for accounting employees, non-accounting employees, top executives (CEOs or CFOs), and directors, respectively. Please refer to the Appendix for detailed variable definitions.

Panel A: Distribution by Year

\begin{tabular}{|c|c|c|c|c|}
\hline Year & $\begin{array}{c}\% \text { Female } \\
\text { _Acct }\end{array}$ & $\begin{array}{l}\text { \%Female } \\
\text { NonAcct }\end{array}$ & $\begin{array}{l}\text { \%Female } \\
\text { CEO/CFO }\end{array}$ & $\begin{array}{l}\% \text { Female } \\
\text { Director }\end{array}$ \\
\hline 2007 & 0.518 & 0.417 & 0.058 & 0.089 \\
\hline 2008 & 0.515 & 0.412 & 0.064 & 0.090 \\
\hline 2009 & 0.514 & 0.412 & 0.064 & 0.093 \\
\hline 2010 & 0.514 & 0.412 & 0.067 & 0.097 \\
\hline 2011 & 0.512 & 0.411 & 0.068 & 0.100 \\
\hline 2012 & 0.506 & 0.414 & 0.071 & 0.106 \\
\hline 2013 & 0.503 & 0.416 & 0.072 & 0.112 \\
\hline 2014 & 0.497 & 0.418 & 0.075 & 0.119 \\
\hline 2015 & 0.498 & 0.422 & 0.085 & 0.128 \\
\hline 2016 & 0.499 & 0.425 & 0.087 & 0.138 \\
\hline 2017 & 0.502 & 0.412 & 0.087 & 0.167 \\
\hline
\end{tabular}

Panel B: Distribution by Industry Sector

\begin{tabular}{lcccc}
\hline Fama-French 12 Industry Sectors & $\begin{array}{c}\text { \%Female } \\
\text { _Acct }\end{array}$ & $\begin{array}{c}\text { \%Female } \\
\text { _NonAcct }\end{array}$ & $\begin{array}{c}\text { \%Female } \\
\text { _CEO/CFO }\end{array}$ & $\begin{array}{c}\text { \%Female } \\
\text { _Director }\end{array}$ \\
\hline Consumer NonDurables & 0.523 & 0.464 & 0.095 & 0.157 \\
Consumer Durables & 0.512 & 0.370 & 0.054 & 0.099 \\
Manufacturing & 0.475 & 0.313 & 0.067 & 0.098 \\
Oil, Gas, and Coal Extraction and Products & 0.538 & 0.331 & 0.036 & 0.063 \\
Chemicals and Allied Products & 0.513 & 0.381 & 0.048 & 0.144 \\
Business Equipment & 0.491 & 0.337 & 0.066 & 0.088 \\
Telephone and Television Transmission & 0.509 & 0.406 & 0.075 & 0.101 \\
Utilities & 0.481 & 0.356 & 0.095 & 0.193 \\
Wholesale, Retail, and Some Services & 0.544 & 0.482 & 0.105 & 0.137 \\
Healthcare, Medical Equipment, and Drugs & 0.500 & 0.482 & 0.064 & 0.101 \\
Finance & 0.511 & 0.514 & 0.076 & 0.113 \\
Other & 0.515 & 0.402 & 0.069 & 0.107 \\
\hline
\end{tabular}


Table 2. Descriptive Statistics

This table reports the summary statistics and the pairwise correlation matrices of selected variables. Please refer to the Appendix for detailed variable definitions.

Panel A: Summary statistics for main variables

\begin{tabular}{|c|c|c|c|c|c|c|}
\hline & $\mathrm{N}$ & Mean & STD & Q1 & Median & Q3 \\
\hline \%Female_Acct & 23,542 & 0.51 & 0.21 & 0.42 & 0.51 & 0.61 \\
\hline$\%$ Female_NonAcct & 23,542 & 0.42 & 0.15 & 0.31 & 0.40 & 0.51 \\
\hline$\%$ Female_CEO/CFO & 23,542 & 0.07 & 0.18 & 0.00 & 0.00 & 0.00 \\
\hline$\%$ Female_Director & 23,542 & 0.11 & 0.11 & 0.00 & 0.11 & 0.18 \\
\hline \#Accountants & 23,542 & 105.27 & 247.78 & 6.38 & 23.46 & 81.99 \\
\hline \#Directors & 23,542 & 8.51 & 2.46 & 7.00 & 8.00 & 10.00 \\
\hline Size & 23,542 & 6.79 & 2.15 & 5.32 & 6.76 & 8.23 \\
\hline Age & 23,542 & 23.48 & 16.07 & 12.00 & 19.00 & 31.00 \\
\hline Growth & 23,542 & 0.12 & 0.51 & -0.04 & 0.05 & 0.17 \\
\hline ROA & 23,542 & -0.03 & 0.27 & -0.02 & 0.02 & 0.07 \\
\hline Loss & 23,542 & 0.30 & 0.46 & 0.00 & 0.00 & 1.00 \\
\hline Leverage & 23,542 & 0.22 & 0.23 & 0.03 & 0.16 & 0.33 \\
\hline Zscore & 23,542 & 3.21 & 6.72 & 0.88 & 2.76 & 4.88 \\
\hline VolROA & 23,542 & 0.12 & 0.30 & 0.02 & 0.04 & 0.11 \\
\hline Foreign & 23,542 & 0.30 & 0.46 & 0.00 & 0.00 & 1.00 \\
\hline Diversification & 23,542 & 0.30 & 0.46 & 0.00 & 0.00 & 1.00 \\
\hline Restruct & 23,542 & 0.30 & 0.46 & 0.00 & 0.00 & 1.00 \\
\hline M\&A & 23,542 & 0.46 & 0.50 & 0.00 & 0.00 & 1.00 \\
\hline \%IndDirector & 23,542 & 0.77 & 0.13 & 0.70 & 0.80 & 0.88 \\
\hline Big4Auditor & 23,542 & 0.71 & 0.45 & 0.00 & 1.00 & 1.00 \\
\hline Analyst & 23,542 & 1.43 & 1.09 & 0.00 & 1.61 & 2.30 \\
\hline \%InstOwnership & 23,542 & 0.59 & 0.32 & 0.32 & 0.67 & 0.87 \\
\hline Return & 21,565 & 0.11 & 0.54 & -0.20 & 0.06 & 0.32 \\
\hline MB & 21,565 & 2.77 & 5.13 & 1.10 & 1.84 & 3.31 \\
\hline ICW_(t+1) & 23,542 & 0.06 & 0.23 & 0.00 & 0.00 & 0.00 \\
\hline ICW_EMP_(t+1) & 22,837 & 0.03 & 0.18 & 0.00 & 0.00 & 0.00 \\
\hline DCW_(t+1) & 23,510 & 0.09 & 0.28 & 0.00 & 0.00 & 0.00 \\
\hline Turnover_Overall_(t+1) & 21,565 & 0.15 & 0.15 & 0.05 & 0.13 & 0.21 \\
\hline Turnover_Female_(t+1) & 21,565 & 0.14 & 0.19 & 0.00 & 0.10 & 0.19 \\
\hline Turnover_Male_(t+1) & 21,565 & 0.17 & 0.23 & 0.00 & 0.13 & 0.23 \\
\hline
\end{tabular}

Panel B: Pairwise Pearson correlations for female-related variables

\begin{tabular}{l|c|c|c|c}
\hline & \%Female_Acct & \%Female_NonAcct & \%Female_CEO/CFO & \%Female_Director \\
\hline \%Female_Acct & 1.000 & & & \\
\%Female_NonAcct & 0.174 & 1.000 & & \\
\%Female_CEO/CFO & 0.099 & 0.086 & 1.000 & \\
\%Female_Director & 0.070 & 0.187 & 0.228 & 1.000 \\
\hline
\end{tabular}


Table 3. Main Results

This table reports the logistic regression results for the effect of \%Female_Acct on the likelihood of one-year-ahead internal control weaknesses $(I C W)$ and employee-specific internal control weaknesses $\left(I C W_{-} E M P\right)$. Industry (FamaFrench 48) and year fixed effects are included. Standard errors are clustered by firm. The $z$-statistics for the two-tailed tests are shown in parentheses. ***,**, and * indicate statistical significance at the $1 \%, 5 \%$, and $10 \%$ levels, respectively. Please refer to the Appendix for detailed variable definitions.

\begin{tabular}{|c|c|c|c|c|}
\hline DV: one-year ahead & $\begin{array}{c}(1) \\
\text { ICW }\end{array}$ & $\begin{array}{c}(2) \\
\text { ICW }\end{array}$ & $\begin{array}{c}(3) \\
\text { ICW_EMP }\end{array}$ & $\begin{array}{c}\text { (4) } \\
\text { ICW_EMP }\end{array}$ \\
\hline \%Female_Acct & $\begin{array}{l}-0.526 * * * \\
(-3.10)\end{array}$ & $\begin{array}{l}-0.503 * * * \\
(-2.92)\end{array}$ & $\begin{array}{l}-0.601 * * * \\
(-2.80)\end{array}$ & $\begin{array}{l}-0.596 * * * * \\
(-2.78)\end{array}$ \\
\hline$\%$ Female_NonAcct & & $\begin{array}{c}0.170 \\
(0.53)\end{array}$ & & $\begin{array}{c}0.525 \\
(1.30)\end{array}$ \\
\hline$\%$ Female_CEO/CFO & & $\begin{array}{l}-0.435^{*} \\
(-1.84)\end{array}$ & & $\begin{array}{l}-0.296 \\
(-1.05)\end{array}$ \\
\hline \%Female_Director & & $\begin{array}{c}0.056 \\
(0.11)\end{array}$ & & $\begin{array}{c}-0.363 \\
(-0.57)\end{array}$ \\
\hline Tail(\%Female_Acct) & $\begin{array}{c}-0.073 \\
(-0.63)\end{array}$ & $\begin{array}{l}-0.069 \\
(-0.59)\end{array}$ & $\begin{array}{c}0.079 \\
(0.53)\end{array}$ & $\begin{array}{c}0.092 \\
(0.62)\end{array}$ \\
\hline Size & $\begin{array}{l}-0.186 * * * \\
(-5.28)\end{array}$ & $\begin{array}{l}-0.187 * * * \\
(-5.17)\end{array}$ & $\begin{array}{l}-0.188 * * * \\
(-3.97)\end{array}$ & $\begin{array}{l}-0.185 * * * \\
(-3.84)\end{array}$ \\
\hline Age & $\begin{array}{l}-0.012 * * * \\
(-3.47)\end{array}$ & $\begin{array}{l}-0.012 * * * \\
(-3.45)\end{array}$ & $\begin{array}{l}-0.016^{* * *} \\
(-3.09)\end{array}$ & $\begin{array}{l}-0.016^{* * * *} \\
(-3.08)\end{array}$ \\
\hline Growth & $\begin{array}{l}0.110 * * \\
(2.48)\end{array}$ & $\begin{array}{l}0.109 * * \\
(2.48)\end{array}$ & $\begin{array}{l}0.094^{*} \\
(1.66)\end{array}$ & $\begin{array}{l}0.094 * \\
(1.65)\end{array}$ \\
\hline ROA & $\begin{array}{c}-0.061 \\
(-0.47)\end{array}$ & $\begin{array}{c}-0.056 \\
(-0.43)\end{array}$ & $\begin{array}{l}-0.039 \\
(-0.25)\end{array}$ & $\begin{array}{c}-0.043 \\
(-0.28)\end{array}$ \\
\hline Loss & $\begin{array}{l}0.490 * * * \\
(5.80)\end{array}$ & $\begin{array}{l}0.490 \text { *** } \\
(5.82)\end{array}$ & $\begin{array}{l}0.470 \text { *** } \\
(4.49)\end{array}$ & $\begin{array}{l}0.471^{* * * *} \\
(4.51)\end{array}$ \\
\hline Leverage & $\begin{array}{l}0.445^{* * *} \\
(3.02)\end{array}$ & $\begin{array}{l}0.442 \text { *** } \\
(2.99)\end{array}$ & $\begin{array}{c}0.257 \\
(1.41)\end{array}$ & $\begin{array}{c}0.246 \\
(1.34)\end{array}$ \\
\hline Zscore & $\begin{array}{c}-0.002 \\
(-0.36)\end{array}$ & $\begin{array}{c}-0.002 \\
(-0.36)\end{array}$ & $\begin{array}{c}-0.005 \\
(-0.85)\end{array}$ & $\begin{array}{c}-0.005 \\
(-0.82)\end{array}$ \\
\hline VolROA & $\begin{array}{c}0.185^{*} \\
(1.89)\end{array}$ & $\begin{array}{l}0.191 * \\
(1.95)\end{array}$ & $\begin{array}{l}0.205^{*} \\
(1.80)\end{array}$ & $\begin{array}{c}0.214^{*} \\
(1.87)\end{array}$ \\
\hline Foreign & $\begin{array}{l}0.157^{*} \\
(1.68)\end{array}$ & $\begin{array}{l}0.157^{*} \\
(1.68)\end{array}$ & $\begin{array}{c}0.166 \\
(1.37)\end{array}$ & $\begin{array}{r}0.167 \\
(1.38)\end{array}$ \\
\hline Diversification & $\begin{array}{l}0.173 * \\
(1.75)\end{array}$ & $\begin{array}{l}0.170^{*} \\
(1.71)\end{array}$ & $\begin{array}{r}0.065 \\
(0.53)\end{array}$ & $\begin{array}{r}0.060 \\
(0.48)\end{array}$ \\
\hline Restruct & $\begin{array}{c}0.140 \\
(1.61)\end{array}$ & $\begin{array}{c}0.136 \\
(1.55)\end{array}$ & $\begin{array}{c}0.143 \\
(1.23)\end{array}$ & $\begin{array}{c}0.139 \\
(1.21)\end{array}$ \\
\hline M\&A & $\begin{array}{l}0.325^{* * *} \\
(4.14)\end{array}$ & $\begin{array}{l}0.320^{* * *} \\
(4.08)\end{array}$ & $\begin{array}{l}0.521^{* * * *} \\
(4.80)\end{array}$ & $\begin{array}{l}0.516^{* * * *} \\
(4.76)\end{array}$ \\
\hline \%IndDirector & $\begin{array}{l}-1.070^{* * *} \\
(-3.51)\end{array}$ & $\begin{array}{l}-1.066^{* * *} \\
(-3.45)\end{array}$ & $\begin{array}{l}-1.099 * * * \\
(-2.82)\end{array}$ & $\begin{array}{l}-1.075^{* * *} \\
(-2.75)\end{array}$ \\
\hline Big4Auditor & $\begin{array}{l}-0.313^{* * *} \\
(-3.20)\end{array}$ & $\begin{array}{l}-0.312^{* * *} \\
(-3.18)\end{array}$ & $\begin{array}{l}-0.368^{* * *} \\
(-2.90)\end{array}$ & $\begin{array}{l}-0.362 * * * \\
(-2.87)\end{array}$ \\
\hline Analyst & $\begin{array}{l}-0.132 * * * \\
(-2.79)\end{array}$ & $\begin{array}{l}-0.134 * * * \\
(-2.81)\end{array}$ & $\begin{array}{l}-0.168 * * * \\
(-2.80)\end{array}$ & $\begin{array}{l}-0.166 * * * \\
(-2.75)\end{array}$ \\
\hline \%InstOwnership & $\begin{array}{l}-0.269^{*} \\
(-1.75)\end{array}$ & $\begin{array}{l}-0.272 * \\
(-1.77)\end{array}$ & $\begin{array}{l}-0.394 * * \\
(-2.01)\end{array}$ & $\begin{array}{l}-0.400 * * \\
(-2.04)\end{array}$ \\
\hline Industry FE & Yes & Yes & Yes & Yes \\
\hline Year FE & Yes & Yes & Yes & Yes \\
\hline Observations & 23,542 & 23,542 & 22,837 & 22,837 \\
\hline Pseudo $\mathrm{R}^{2}$ & 0.106 & 0.106 & 0.129 & 0.130 \\
\hline
\end{tabular}


Table 4. Piecewise Regressions

This table reports the piecewise logistic regression results for the effect of \%Female_Acct on one-year-ahead ICW and $I C W_{-} E M P . \%$ Female_Acct_Below ${ }_{50}=\%$ Female_Acct if $0 \leq \%$ Female_Acct $\leq 0.5,=0.5$ if $0.5<\%$ Female_Acct $\leq$ $1 . \%$ Female_Acct_Above $50=0$ if $\%$ Female_Acct $\leq 0.5,=(\%$ Female_Acct -0.5$)$ if $0.5<\%$ Female_Acct $\leq 1$. Industry (Fama-French 48) and year fixed effects are included. Standard errors are clustered by firm. The $z$-statistics for the two-tailed tests are shown in parentheses. $* * *, * *$, and $*$ indicate statistical significance at the $1 \%, 5 \%$, and $10 \%$ levels, respectively. Please refer to the Appendix for detailed variable definitions.

\begin{tabular}{lcc|cc}
\hline & $(1)$ & $(2)$ & $(3)$ & $(4)$ \\
DV: one-year ahead & ICW & ICW & ICW_EMP & ICW_EMP \\
\hline \%Female_Acct_Below50 & $\mathbf{- 1 . 1 6 6 * * *}$ & $\mathbf{- 1 . 1 4 2 * * *}$ & $\mathbf{- 1 . 3 3 1 * *}$ & $\mathbf{- 1 . 2 9 4} * *$ \\
& $\mathbf{( - 2 . 7 8 )}$ & $\mathbf{( - 2 . 7 2 )}$ & $\mathbf{( - 2 . 4 9 )}$ & $\mathbf{( - 2 . 4 2 )}$ \\
\%Female_Acct_Above50 & $\mathbf{0 . 1 2 4}$ & $\mathbf{0 . 1 4 9}$ & $\mathbf{0 . 1 4 6}$ & $\mathbf{0 . 1 2 2}$ \\
& $\mathbf{( 0 . 2 7 )}$ & $\mathbf{( 0 . 3 2 )}$ & $\mathbf{( 0 . 2 4 )}$ & $\mathbf{( 0 . 2 0 )}$ \\
\%Female_NonAcct & & 0.145 & & 0.499 \\
& & $(0.46)$ & & $(1.25)$ \\
\%Female_CEO/CFO & & $-0.440 *$ & & -0.299 \\
& & $(-1.85)$ & & $(-1.06)$ \\
\%Female_Director & & 0.061 & & -0.360 \\
& & $(0.12)$ & & $(-0.57)$ \\
Other Controls & & Yes & & \\
Industry FE & Yes & Yes & Yes & Yes \\
Year FE & Yes & Yes & Yes & Yes \\
Observations & Yes & 23,542 & 22,837 & Yes \\
Pseudo R ${ }^{2}$ & 23,542 & 0.107 & 0.130 & 0.130 \\
\hline
\end{tabular}


Table 5. Entropy balance matching analysis

Panel A reports the logistic regression results for the determinant model of High_\%Female_Acct ( $=1$ if \%Female_Acct is higher than the sample median sorted annually) in Columns (1) and (2) and reports the $t$-test for the covariates after the entropy balance matching in Columns (3) to (6). Panel B reports the logistic regression results using the entropy balance matched sample. \%Female_Acct_Below ${ }_{50}=\%$ Female_Acct if $0 \leq \%$ Female_Acct $\leq 0.5,=0.5$ if 0.5 $<\%$ Female_Acct $\leq 1$. \%Female_Acct_Above $50=0$ if $\%$ Female_Acct $\leq 0.5,=(\%$ Female_Acct -0.5$)$ if 0.5 $<\%$ Female_Acct $\leq 1$. Industry (Fama-French 48 ) and year fixed effects are included. Standard errors are clustered by firm. The $z$-statistics for the two-tailed tests are shown in parentheses. $* * * * *$, and $*$ indicate statistical significance at the $1 \%, 5 \%$, and $10 \%$ levels, respectively. Please refer to the Appendix for detailed variable definitions.

Panel A: Determinants for \%Female_Acct and characteristics for post-matched sample

\begin{tabular}{|c|c|c|c|c|c|c|}
\hline & \multicolumn{2}{|c|}{$\begin{array}{c}\text { Determinant Model: } \\
\text { DV: High_\%Female_Acct }\end{array}$} & \multicolumn{4}{|c|}{$\begin{array}{l}\text { Post Entropy Balance Matched Sample Characteristics } \\
\text { High_\%Female_Acct: }\end{array}$} \\
\hline \%Female_NonAcct & $2.483 * * *$ & 8.35 & 0.445 & 0.445 & 0.000 & 0.06 \\
\hline$\%$ Female_CEO/CFO & $0.595 * * *$ & 3.79 & 0.084 & 0.084 & 0.000 & 0.01 \\
\hline$\%$ Female_Director & $0.622 * *$ & 2.05 & 0.116 & 0.116 & 0.000 & 0.02 \\
\hline Tail(\%Female_Acct) & -0.164 & -1.46 & 0.093 & 0.093 & 0.000 & -0.05 \\
\hline Size & $-0.057 * *$ & -2.07 & 6.823 & 6.822 & 0.001 & 0.03 \\
\hline Age & $-0.004 *$ & -1.66 & 23.015 & 23.014 & 0.001 & 0.00 \\
\hline Growth & -0.027 & -0.86 & 0.115 & 0.115 & 0.000 & -0.01 \\
\hline ROA & 0.119 & 1.04 & -0.025 & -0.025 & 0.000 & 0.04 \\
\hline Loss & -0.004 & -0.07 & 0.290 & 0.290 & 0.000 & -0.02 \\
\hline Leverage & -0.037 & -0.26 & 0.215 & 0.215 & 0.000 & 0.00 \\
\hline Zscore & -0.001 & -0.18 & 3.249 & 3.247 & 0.001 & 0.01 \\
\hline VolROA & 0.034 & 0.34 & 0.112 & 0.112 & 0.000 & -0.03 \\
\hline Foreign & -0.049 & -0.70 & 0.283 & 0.284 & 0.000 & -0.01 \\
\hline Diversification & 0.053 & 0.77 & 0.307 & 0.307 & 0.000 & 0.01 \\
\hline Restruct & -0.063 & -1.17 & 0.288 & 0.288 & 0.000 & 0.00 \\
\hline M\&A & $0.143 * * *$ & 3.02 & 0.475 & 0.475 & 0.000 & 0.02 \\
\hline$\%$ IndDirector & -0.250 & -1.04 & 0.770 & 0.770 & 0.000 & 0.01 \\
\hline Big4Auditor & 0.075 & 0.90 & 0.718 & 0.718 & 0.000 & 0.02 \\
\hline Analyst & -0.015 & -0.40 & 1.434 & 1.434 & 0.000 & 0.02 \\
\hline \%InstOwnership & $0.245^{* *}$ & 2.16 & 0.598 & 0.598 & 0.000 & 0.03 \\
\hline
\end{tabular}


Panel B: Logistic regression results using the matched sample

\begin{tabular}{|c|c|c|c|c|}
\hline DV: one-year ahead & $\begin{array}{c}(1) \\
\text { ICW }\end{array}$ & $\begin{array}{c}(2) \\
\text { ICW }\end{array}$ & $\begin{array}{c}(3) \\
\text { ICW_EMP }\end{array}$ & $\begin{array}{c}\text { (4) } \\
\text { ICW_EMP }\end{array}$ \\
\hline \%Female_Acct & $\begin{array}{l}-0.484 * * * \\
(-2.67)\end{array}$ & & $\begin{array}{l}-0.519 * * \\
(-2.33)\end{array}$ & \\
\hline \%Female_Acct_Below50 & & $\begin{array}{l}-1.178 * * * \\
(-2.78)\end{array}$ & & $\begin{array}{l}-1.251 * * \\
(-2.26)\end{array}$ \\
\hline \%Female_Acct_Above 50 & & $\begin{array}{c}0.210 \\
(0.45)\end{array}$ & & $\begin{array}{r}0.217 \\
(\mathbf{0 . 3 5})\end{array}$ \\
\hline$\%$ Female_NonAcct & $\begin{array}{r}0.231 \\
(0.70)\end{array}$ & $\begin{array}{r}0.212 \\
(0.64)\end{array}$ & $\begin{array}{c}0.618 \\
(1.50)\end{array}$ & $\begin{array}{r}0.597 \\
(1.47)\end{array}$ \\
\hline$\%$ Female_CEO/CFO & $\begin{array}{l}-0.448^{*} \\
(-1.74)\end{array}$ & $\begin{array}{l}-0.447 * \\
(-1.73)\end{array}$ & $\begin{array}{c}-0.394 \\
(-1.31)\end{array}$ & $\begin{array}{l}-0.391 \\
(-1.30)\end{array}$ \\
\hline$\%$ Female_Director & $\begin{array}{r}0.387 \\
(0.64)\end{array}$ & $\begin{array}{r}0.387 \\
(0.65)\end{array}$ & $\begin{array}{r}0.026 \\
(0.04)\end{array}$ & $\begin{array}{r}0.021 \\
(0.03)\end{array}$ \\
\hline Other Controls & Yes & Yes & Yes & Yes \\
\hline EB Matched Sample & Yes & Yes & Yes & Yes \\
\hline Industry FE & Yes & Yes & Yes & Yes \\
\hline Year FE & Yes & Yes & Yes & Yes \\
\hline Observations & 23,542 & 23,542 & 22,837 & 22,837 \\
\hline Pseudo $\mathrm{R}^{2}$ & 0.101 & 0.102 & 0.121 & 0.121 \\
\hline
\end{tabular}


Table 6. Turnover

This table reports the OLS regression results for the effect of ICW on the one-year-ahead turnover of accounting employees in the pooled sample and in the subsamples partitioned using the midpoint of \%Female_Acct. Dependent variables include the one-year-ahead turnover for all accountants, female accountants, and male accountants. Industry (Fama-French 48) and year fixed effects are included. Standard errors are clustered by firm. The $t$-statistics for two-tailed tests are shown in parentheses. $* * *, * *$, and $*$ indicate statistical significance at the $1 \%, 5 \%$, and $10 \%$ levels, respectively. Please refer to the Appendix for detailed variable definitions.

\begin{tabular}{|c|c|c|c|c|c|c|c|c|c|}
\hline & \multicolumn{3}{|c|}{ Pooled Sample } & \multicolumn{3}{|c|}{ Subsample: $0 \leq \%$ Female Acct $\leq 0.5$} & \multicolumn{3}{|c|}{ Subsample: $0.5<\%$ Female Acct $\leq 1$} \\
\hline & (1) & $(2)$ & (3) & (4) & $(5)$ & $(6)$ & $(7)$ & $(8)$ & $(9)$ \\
\hline DV: one-year-ahead turnover & Overall & Female & Male & Overall & Female & Male & Overall & Female & Male \\
\hline ICW & $\begin{array}{l}0.024 * * * \\
(3.92)\end{array}$ & $\begin{array}{c}0.011 \\
(1.35)\end{array}$ & $\begin{array}{l}\text { 0.034*** } \\
(3.73)\end{array}$ & $\begin{array}{l}\text { 0.031*** } \\
(3.36)\end{array}$ & $\begin{array}{r}0.011 \\
(1.03)\end{array}$ & $\begin{array}{l}0.045 * * * \\
(3.23)\end{array}$ & $\begin{array}{l}0.018 * * \\
(2.26)\end{array}$ & $\begin{array}{r}0.012 \\
(1.19)\end{array}$ & $\begin{array}{l}0.023 * * \\
(2.00)\end{array}$ \\
\hline $\begin{array}{l}p \text { value for the } F \text {-test for the } c \\
\text { Female and Male regressions }\end{array}$ & f. across & & & & & & & & \\
\hline Return & $\begin{array}{l}-0.012 * * * \\
(-5.15)\end{array}$ & $\begin{array}{l}-0.009 * * * \\
(-3.11)\end{array}$ & $\begin{array}{l}-0.015 * * * \\
(-4.14)\end{array}$ & $\begin{array}{l}-0.011 \text { *** } \\
(-2.92)\end{array}$ & $\begin{array}{c}-0.005 \\
(-0.94)\end{array}$ & $\begin{array}{l}-0.016^{* * *} \\
(-2.93)\end{array}$ & $\begin{array}{l}-0.012 * * * \\
(-4.30)\end{array}$ & $\begin{array}{l}-0.013 * * * \\
(-3.60)\end{array}$ & $\begin{array}{l}-0.014 * * * \\
(-2.83)\end{array}$ \\
\hline ROA & $\begin{array}{l}-0.036 * * * \\
(-3.35)\end{array}$ & $\begin{array}{l}-0.047 * * * \\
(-3.13)\end{array}$ & $\begin{array}{l}-0.035^{* *} \\
(-2.19)\end{array}$ & $\begin{array}{l}-0.027 * \\
(-1.66)\end{array}$ & $\begin{array}{l}-0.047 * * \\
(-2.14)\end{array}$ & $\begin{array}{c}-0.026 \\
(-1.06)\end{array}$ & $\begin{array}{l}-0.044 * * * \\
(-3.03)\end{array}$ & $\begin{array}{l}-0.050 * * \\
(-2.47)\end{array}$ & $\begin{array}{l}-0.037 * \\
(-1.95)\end{array}$ \\
\hline Loss & $\begin{array}{l}0.018 \text { *** } \\
(5.17)\end{array}$ & $\begin{array}{l}0.014 * * * \\
(3.29)\end{array}$ & $\begin{array}{l}0.023 * * * \\
(4.39)\end{array}$ & $\begin{array}{l}0.017 * * * \\
(3.15)\end{array}$ & $\begin{array}{c}0.010 \\
(1.45)\end{array}$ & $\begin{array}{l}0.025^{* * *} \\
(3.06)\end{array}$ & $\begin{array}{l}0.018 \text { *** } \\
(4.06)\end{array}$ & $\begin{array}{l}0.018 \text { *** } \\
(3.13)\end{array}$ & $\begin{array}{l}0.021 \text { *** } \\
(3.31)\end{array}$ \\
\hline MB & $\begin{array}{c}0.000 \\
(1.59)\end{array}$ & $\begin{array}{c}-0.000 \\
(-0.12)\end{array}$ & $\begin{array}{l}0.001 * * \\
(2.21)\end{array}$ & $\begin{array}{c}0.000 \\
(1.44)\end{array}$ & $\begin{array}{c}0.000 \\
(0.02)\end{array}$ & $\begin{array}{c}0.001 \\
(1.35)\end{array}$ & $\begin{array}{c}0.000 \\
(0.54)\end{array}$ & $\begin{array}{c}-0.000 \\
(-0.11)\end{array}$ & $\begin{array}{c}0.001 \\
(1.45)\end{array}$ \\
\hline Size & $\begin{array}{l}0.006 \text { *** } \\
(5.49)\end{array}$ & $\begin{array}{l}0.004 * * * \\
(2.84)\end{array}$ & $\begin{array}{l}0.006 \text { *** } \\
(3.92)\end{array}$ & $\begin{array}{l}0.006 \text { *** } \\
(3.82)\end{array}$ & $\begin{array}{l}0.005^{* *} \\
(2.24)\end{array}$ & $\begin{array}{l}0.005^{* *} \\
(2.14)\end{array}$ & $\begin{array}{l}0.004 * * * \\
(3.26)\end{array}$ & $\begin{array}{c}0.002 \\
(1.09)\end{array}$ & $\begin{array}{l}0.005^{* * *} \\
(2.76)\end{array}$ \\
\hline Age & $\begin{array}{l}-0.000 * * * \\
(-5.70)\end{array}$ & $\begin{array}{l}-0.000 * * * \\
(-4.28)\end{array}$ & $\begin{array}{l}-0.001 * * * \\
(-3.95)\end{array}$ & $\begin{array}{l}-0.001 * * * \\
(-4.98)\end{array}$ & $\begin{array}{l}-0.001 * * * \\
(-3.19)\end{array}$ & $\begin{array}{l}-0.001 * * * \\
(-4.03)\end{array}$ & $\begin{array}{l}-0.000 * * * \\
(-3.17)\end{array}$ & $\begin{array}{l}-0.000 * * * \\
(-2.95)\end{array}$ & $\begin{array}{l}-0.000 * * \\
(-2.12)\end{array}$ \\
\hline Growth & $\begin{array}{c}0.000 \\
(0.05)\end{array}$ & $\begin{array}{c}-0.001 \\
(-0.22)\end{array}$ & $\begin{array}{c}0.003 \\
(0.63)\end{array}$ & $\begin{array}{c}0.004 \\
(0.72)\end{array}$ & $\begin{array}{c}0.003 \\
(0.51)\end{array}$ & $\begin{array}{c}0.005 \\
(0.64)\end{array}$ & $\begin{array}{c}-0.004 \\
(-1.09)\end{array}$ & $\begin{array}{c}-0.005 \\
(-1.08)\end{array}$ & $\begin{array}{c}0.001 \\
(0.13)\end{array}$ \\
\hline Leverage & $\begin{array}{c}-0.000 \\
(-0.05)\end{array}$ & $\begin{array}{c}0.003 \\
(0.39)\end{array}$ & $\begin{array}{c}-0.007 \\
(-0.77)\end{array}$ & $\begin{array}{c}-0.009 \\
(-0.82)\end{array}$ & $\begin{array}{c}-0.009 \\
(-0.64)\end{array}$ & $\begin{array}{c}-0.011 \\
(-0.70)\end{array}$ & $\begin{array}{c}0.006 \\
(0.79)\end{array}$ & $\begin{array}{c}0.013 \\
(1.24)\end{array}$ & $\begin{array}{c}-0.004 \\
(-0.33)\end{array}$ \\
\hline Zscore & $\begin{array}{c}-0.000 \\
(-0.39)\end{array}$ & $\begin{array}{c}0.000 \\
(1.00)\end{array}$ & $\begin{array}{c}-0.000 \\
(-0.41)\end{array}$ & $\begin{array}{c}-0.000 \\
(-0.79)\end{array}$ & $\begin{array}{c}0.001 \\
(0.98)\end{array}$ & $\begin{array}{c}-0.001 \\
(-1.12)\end{array}$ & $\begin{array}{c}-0.000 \\
(-0.08)\end{array}$ & $\begin{array}{c}-0.000 \\
(-0.00)\end{array}$ & $\begin{array}{c}0.000 \\
(0.41)\end{array}$ \\
\hline VolROA & $\begin{array}{c}-0.005 \\
(-0.63)\end{array}$ & $\begin{array}{c}-0.006 \\
(-0.61)\end{array}$ & $\begin{array}{r}-0.007 \\
(-0.68)\end{array}$ & $\begin{array}{c}0.008 \\
(0.59)\end{array}$ & $\begin{array}{c}0.008 \\
(0.48)\end{array}$ & $\begin{array}{c}0.010 \\
(0.54)\end{array}$ & $\begin{array}{l}-0.019 * * \\
(-2.34)\end{array}$ & $\begin{array}{l}-0.021 * \\
(-1.87)\end{array}$ & $\begin{array}{l}-0.023 * * \\
(-2.08)\end{array}$ \\
\hline Foreign & $\begin{array}{c}0.000 \\
(0.09)\end{array}$ & $\begin{array}{c}-0.002 \\
(-0.47)\end{array}$ & $\begin{array}{c}0.001 \\
(0.21)\end{array}$ & $\begin{array}{c}-0.001 \\
(-0.17)\end{array}$ & $\begin{array}{c}-0.003 \\
(-0.60)\end{array}$ & $\begin{array}{r}0.000 \\
(0.05)\end{array}$ & $\begin{array}{c}0.000 \\
(0.04)\end{array}$ & $\begin{array}{c}-0.001 \\
(-0.24)\end{array}$ & $\begin{array}{c}0.001 \\
(0.20)\end{array}$ \\
\hline Diversification & $\begin{array}{c}-0.003 \\
(-1.13)\end{array}$ & $\begin{array}{c}-0.004 \\
(-1.11)\end{array}$ & $\begin{array}{l}-0.005 \\
(-1.36)\end{array}$ & $\begin{array}{c}0.004 \\
(0.86)\end{array}$ & $\begin{array}{c}-0.002 \\
(-0.41)\end{array}$ & $\begin{array}{c}0.005 \\
(0.88)\end{array}$ & $\begin{array}{l}-0.009 * * * \\
(-2.72)\end{array}$ & $\begin{array}{c}-0.007 \\
(-1.62)\end{array}$ & $\begin{array}{l}-0.014 * * * \\
(-2.98)\end{array}$ \\
\hline
\end{tabular}




\begin{tabular}{|c|c|c|c|c|c|c|c|c|c|}
\hline Restruct & $\begin{array}{l}0.008 * * * \\
(3.29)\end{array}$ & $\begin{array}{l}0.007 * * \\
(2.07)\end{array}$ & $\begin{array}{l}0.012^{* * * *} \\
(3.14)\end{array}$ & $\begin{array}{c}0.005 \\
(1.24)\end{array}$ & $\begin{array}{l}0.005 \\
(1.03)\end{array}$ & $\begin{array}{c}0.006 \\
(1.09)\end{array}$ & $\begin{array}{l}0.010 * * * \\
(3.04)\end{array}$ & $\begin{array}{c}0.007 \\
(1.64)\end{array}$ & $\begin{array}{l}0.014 \text { **** } \\
(2.89)\end{array}$ \\
\hline \multirow[t]{2}{*}{ M\&A } & $0.008 * * *$ & $0.010 * * *$ & 0.004 & $0.010 * *$ & $0.014 * * *$ & 0.008 & $0.005^{*}$ & $0.007 *$ & -0.001 \\
\hline & $(3.21)$ & $(3.16)$ & $(1.11)$ & $(2.52)$ & $(2.65)$ & $(1.52)$ & $(1.85)$ & $(1.72)$ & $(-0.23)$ \\
\hline \multirow[t]{2}{*}{$\%$ IndDirector } & $0.043 * * *$ & $0.031 * *$ & $0.044 * * *$ & $0.067 * * *$ & 0.035 & $0.086 * * *$ & $0.023 *$ & 0.023 & 0.011 \\
\hline & $(4.16)$ & $(2.33)$ & (2.69) & $(3.80)$ & $(1.58)$ & $(3.23)$ & $(1.87)$ & $(1.46)$ & $(0.56)$ \\
\hline \multirow[t]{2}{*}{ Big4Auditor } & 0.001 & -0.001 & 0.001 & -0.001 & -0.003 & 0.001 & 0.004 & 0.001 & 0.003 \\
\hline & $(0.39)$ & $(-0.20)$ & $(0.23)$ & $(-0.21)$ & $(-0.38)$ & $(0.10)$ & $(0.97)$ & $(0.17)$ & $(0.40)$ \\
\hline \multirow[t]{2}{*}{ Analyst } & $0.005 * * *$ & $0.005 * * *$ & $0.005^{* * *}$ & $0.007 * * *$ & $0.005^{* *}$ & $0.008 * * *$ & $0.004 * *$ & $0.005 * *$ & 0.003 \\
\hline & $(3.77)$ & $(2.79)$ & $(2.71)$ & $(3.18)$ & $(1.98)$ & $(2.67)$ & $(2.38)$ & $(2.21)$ & $(1.35)$ \\
\hline \multirow[t]{2}{*}{$\%$ InstOwnership } & -0.007 & -0.004 & -0.011 & -0.003 & 0.006 & -0.009 & $-0.012 *$ & $-0.013^{*}$ & -0.016 \\
\hline & $(-1.50)$ & $(-0.68)$ & $(-1.44)$ & $(-0.38)$ & $(0.55)$ & $(-0.83)$ & $(-1.87)$ & $(-1.67)$ & $(-1.61)$ \\
\hline \multirow[t]{2}{*}{ Tail(\%Female_Acct) } & -0.001 & $-0.024 * *$ & $-0.036 * * *$ & 0.014 & -0.013 & 0.016 & 0.013 & -0.004 & -0.024 \\
\hline & $(-0.13)$ & $(-2.23)$ & $(-2.86)$ & $(0.83)$ & $(-0.69)$ & $(0.71)$ & $(0.84)$ & $(-0.23)$ & $(-1.27)$ \\
\hline \multirow[t]{2}{*}{ \%Female_Acct } & $-0.036 * * *$ & $0.035^{* * *}$ & $-0.089 * * *$ & 0.012 & $0.068 * *$ & 0.029 & $-0.073 * * *$ & -0.019 & $-0.160 * * *$ \\
\hline & $(-3.52)$ & $(2.89)$ & $(-6.36)$ & $(0.47)$ & $(2.04)$ & $(0.79)$ & $(-3.49)$ & $(-0.69)$ & $(-5.03)$ \\
\hline \multirow[t]{2}{*}{$\%$ Female_NonAcct } & 0.000 & $0.027 *$ & -0.019 & -0.011 & $0.045^{*}$ & -0.034 & 0.013 & 0.018 & -0.008 \\
\hline & $(0.03)$ & $(1.74)$ & $(-0.94)$ & $(-0.46)$ & $(1.80)$ & $(-1.05)$ & $(0.81)$ & $(0.93)$ & $(-0.35)$ \\
\hline \multirow[t]{2}{*}{ \%Female_CEO/CFO } & $0.015 * *$ & $0.023 * *$ & 0.016 & 0.004 & 0.024 & -0.003 & $0.021 * *$ & $0.019 *$ & $0.029 * *$ \\
\hline & $(2.04)$ & $(2.23)$ & $(1.34)$ & $(0.30)$ & $(1.22)$ & $(-0.14)$ & $(2.40)$ & $(1.78)$ & $(1.98)$ \\
\hline \multirow[t]{2}{*}{ \%Female_Director } & $0.027 * *$ & $0.043^{* * *}$ & 0.010 & 0.020 & 0.034 & 0.012 & $0.032 * *$ & $0.054 * * *$ & 0.008 \\
\hline & $(2.07)$ & (2.69) & $(0.45)$ & $(0.93)$ & $(1.33)$ & $(0.36)$ & $(2.04)$ & (2.59) & $(0.33)$ \\
\hline Industry FE & Yes & Yes & Yes & Yes & Yes & Yes & Yes & Yes & Yes \\
\hline Year FE & Yes & Yes & Yes & Yes & Yes & Yes & Yes & Yes & Yes \\
\hline Observations & 21,565 & 21,565 & 21,565 & 9,724 & 9,724 & 9,724 & 11,841 & 11,841 & 11,841 \\
\hline Adjusted $\mathrm{R}^{2}$ & 0.042 & 0.020 & 0.030 & 0.041 & 0.014 & 0.036 & 0.045 & 0.027 & 0.028 \\
\hline
\end{tabular}




\section{Table 7. Robustness}

This table reports robustness tests. Panel A reports the logistic regression results for \%Female_Acct on one-year-ahead $I C W$ and $I C W \_E M P$ after excluding finance and utilities industries. Panel B reports the logistic regression results for \%Female_Acct on one-year-ahead material weaknesses of disclosure control $(D C W)$ and of both internal control and disclosure control $\left(I C W_{-} D C W\right)$. \%Female_Acct_Below $50=\%$ Female_Acct if $0 \leq \%$ Female_Acct $\leq 0.5,=0.5$ if $0.5<\%$ Female_Acct $\leq 1 . \%$ Female_Acct_Above $50=0$ if $\%$ Female_Acct $\leq 0.5,=(\%$ Female_Acct -0.5$)$ if 0.5 $<\%$ Female_Acct $\leq 1$. Industry (Fama-French 48) and year fixed effects are included. Standard errors are clustered by firm. The $z$-statistics for two-tailed tests are shown in parentheses. $* * *, * *$, and $*$ indicate statistical significance at the $1 \%, 5 \%$, and $10 \%$ levels, respectively. Please refer to the Appendix for detailed variable definitions.

Panel A: Excluding financial industries and utilities industries

\begin{tabular}{|c|c|c|c|c|}
\hline DV: one-year ahead & $\begin{array}{c}(1) \\
\mathrm{ICW}\end{array}$ & $\begin{array}{c}(2) \\
\mathrm{ICW}\end{array}$ & $\begin{array}{c}(3) \\
\text { ICW_EMP }\end{array}$ & $\begin{array}{c}(4) \\
\text { ICW_EMP }\end{array}$ \\
\hline \%Female_Acct & $\begin{array}{l}-0.556 * * * \\
(-2.91)\end{array}$ & & $\begin{array}{l}-0.570 * * \\
(-2.44)\end{array}$ & \\
\hline \%Female_Acct_Below50 & & $\begin{array}{l}-1.190 * * * \\
(-2.67)\end{array}$ & & $\begin{array}{l}-1.429 * * \\
(-2.50)\end{array}$ \\
\hline \%Female_Acct_Above 50 & & $\begin{array}{c}0.093 \\
(\mathbf{0 . 1 8})\end{array}$ & & $\begin{array}{c}0.312 \\
(0.48)\end{array}$ \\
\hline$\%$ Female_NonAcct & $\begin{array}{r}0.255 \\
(0.71)\end{array}$ & $\begin{array}{c}0.224 \\
(0.63)\end{array}$ & $\begin{array}{c}0.485 \\
(1.04)\end{array}$ & $\begin{array}{c}0.447 \\
(0.97)\end{array}$ \\
\hline \%Female_CEO/CFO & $\begin{array}{l}-0.599 * * \\
(-2.25)\end{array}$ & $\begin{array}{l}-0.602^{* *} \\
(-2.26)\end{array}$ & $\begin{array}{l}-0.531^{*} \\
(-1.69)\end{array}$ & $\begin{array}{l}-0.533^{*} \\
(-1.70)\end{array}$ \\
\hline$\%$ Female_Director & $\begin{array}{c}0.259 \\
(0.50)\end{array}$ & $\begin{array}{c}0.259 \\
(0.50)\end{array}$ & $\begin{array}{c}-0.326 \\
(-0.50)\end{array}$ & $\begin{array}{c}-0.326 \\
(-0.50)\end{array}$ \\
\hline Other Controls & Yes & Yes & Yes & Yes \\
\hline Industry FE & Yes & Yes & Yes & Yes \\
\hline Year FE & Yes & Yes & Yes & Yes \\
\hline Observations & 18,587 & 18,587 & 17,978 & 17,978 \\
\hline Pseudo $\mathrm{R}^{2}$ & 0.112 & 0.112 & 0.131 & 0.131 \\
\hline
\end{tabular}

Panel B: Disclosure control weakness

\begin{tabular}{lcc|cc}
\hline & $(1)$ & $(2)$ & $(3)$ & $(4)$ \\
DV: one-year ahead & DCW & DCW & ICW_DCW & ICW_DCW \\
\hline \%Female_Acct & $\mathbf{- 0 . 4 7 9 * * *}$ & & $\mathbf{- 0 . 5 0 0} * * *$ & \\
& $\mathbf{( - 3 . 0 5}$ & $\mathbf{( - 2 . 8 1 )}$ & $\mathbf{- 1 . 1 1 4 * *}$ \\
\%Female_Acct_Below50 & & $\mathbf{- 0 . 7 4 7} *$ & & $\mathbf{( - 2 . 5 5 )}$ \\
& & $\mathbf{- 1 . 8 7 )}$ & & $\mathbf{0 . 1 2 7}$ \\
\%Female_Acct_Above50 & & $\mathbf{- 0 . 2 0 9}$ & & $\mathbf{( . 2 7 )}$ \\
& & $\mathbf{- 0 . 5 0 )}$ & & 0.264 \\
\%Female_NonAcct & 0.308 & 0.299 & 0.288 & $(0.83)$ \\
& $(1.08)$ & $(1.05)$ & $(0.89)$ & $-0.417^{*}$ \\
\%Female_CEO/CFO & $-0.352^{*}$ & $-0.353^{*}$ & $-0.414 *$ & $(-1.73)$ \\
& $(-1.72)$ & $(-1.72)$ & $(-1.72)$ & 0.088 \\
\%Female_Director & 0.160 & 0.163 & 0.082 & $(0.17)$ \\
& $(0.38)$ & $(0.38)$ & $(0.16)$ & Yes \\
Other Controls & Yes & Yes & Yes & Yes \\
Industry FE & Yes & Yes & Yes & Yes \\
Year FE & Yes & Yes & Yes & 23,510 \\
Observations & 23,510 & 23,510 & 23,510 & 0.100 \\
Pseudo R & 0.091 & 0.091 & 0.100 & \\
\hline
\end{tabular}

